\title{
Development-Related Biases in Factor Productivities and the HOV Model of Trade
}

\author{
KeITH E. MASKUS \\ SHUICHIRO NISHIOKA
}

CESIFO WORKING PAPER No. 2253

CATEgORY 7: TRAde Policy

MARCH 2008
An electronic version of the paper may be downloaded
- from the SSRN website:
- from the RePEc website:
www.SSRN.com
www.RePEc.org
- from the CESifo website:
www.CESifo-group.org/wp




\title{
Development-Related Biases in Factor Productivities and the HOV Model of Trade
}

\begin{abstract}
Past empirical failures of the basic Heckscher-Ohlin-Vanek (HOV) model related to the inability of data to meet its restrictive assumptions, particularly identical international technologies and factor price equalization. Trefler (1993) tried to resuscitate HOV by introducing a simple Hicks-neutral (HN) factor-productivity adjustment, an approach that was heavily criticized. In this paper, we re-examine the productivity question by estimating factorspecific productivities from the individual technology data of multiple countries. Using a dataset of 29 countries, both developed and developing, we find evidence of factoraugmenting technological differences. In particular, the factor-productivity adjustment works well for developed members of the OECD. Further, we find that the ratios of factor productivities are strongly correlated with corresponding factor endowments. This systematic bias implies that the ability of HOV to explain North-South factor trade depends both on relative factor abundance and factor-augmenting productivity gaps.
\end{abstract}

JEL Code: F10, F11.

Keywords: Heckscher-Ohlin-Vanek, factor trade, productivity.

\author{
Keith E. Maskus \\ Department of Economics \\ University of Colorado at Boulder \\ 256 UBC Boulder CO 80309-0256 \\ USA \\ keith.maskus@colorado.edu
}

\author{
Shuichiro Nishioka \\ Department of Economics \\ West Virginia University \\ PO Box 6025 \\ Morgantown WV 26506-025 \\ USA
}

shuichiro.nishioka@mail.wvu.edu

February 2008

We thank Ron Balvers, Keith Head, Wolfgang Keller, James Markusen, and two referees for helpful comments. All errors remain our responsibility. 


\section{Introduction}

Early tests of the Heckscher-Ohlin-Vanek (HOV) model of international factor trade demonstrated that it failed to predict trade better than a coin toss (Maskus, 1985; Bowen, Leamer and Sveikausas, 1987). As noted by Maskus (1985), the assumptions of the strict HOV model are too unrealistic to expect them to generate actual data. ${ }^{1}$ Later tests relaxed many of these assumptions to generate extended HOV models that were more consistent with data (Trefler, 1995; Davis, et al, 1997; Davis and Weinstein, 2001; Hakura, 2001). Much of this analysis has focused on the unrealistic assumptions of internationally identical technologies and factor price equalization (FPE).

Trefler (1993) made a first important step to integrate international differences in factorprices into the HOV model. He introduced a simple Hicks-neutral (HN) productivity modification at the individual factor level to measure endowments in productivity-equivalent units. For example, if the labor supplies of the United States and Brazil were the same, but U.S. workers were twice as productive, the former nation would have twice as much labor at the productivity-equivalent level. ${ }^{2}$ At the same time, the wage of U.S. workers would be twice that of Brazilian workers and ratios of factor prices could be used to infer relative productivities. This modification is consistent with the HOV model after adjusting for international differences in factor productivity.

Davis and Weinstein (2001) argued that Trefler's productivity modification is incomplete because it fails to introduce general differences in technology. With step-by-step relaxations of

\footnotetext{
${ }^{1}$ The strict version assumes: (1) identical constant returns to scale (CRS) technology and factor price equalization; (2) perfectly competitive markets in goods and factors; (3) identical and homothetic preferences; (4) factor endowment differences; and (5) free trade in goods but not factors.

2 This was Leontief's (1953) conjecture to explain his celebrated paradox.
} 
the standard HOV assumptions, they found substantial improvements in prediction power when national technologies are modified according to factor abundance measures.

Though both studies focused on modifying FPE, the conceptual distinction between their empirical approaches is important. Is it differences in productivity of factors or underlying technology that is responsible for factor price disparity? If it is because of factor-productivity differences, the HOV model is fundamentally acceptable, for its failures would come from the inability to measure factors in productivity-equivalent units. However, if the failures occur because of general technology differences, both the standard HOV model and FPE break down.

Several papers analyzing factor abundance have relied on Trefler's method to justify the introduction of productivity adjustments (Trefler, 1995; Antweiler and Trefler, 2002; Debaere, 2003; Debaere and Demiroglu, 2003; Fitzgerald and Hallak, 2004). However, the validity of his results has been questioned. Gabaix (1997), for example, showed that Trefler's adjustment to labor productivity (capital productivity) merely reflects differences in GDP/labor (or GDP/capital) due to his method of deriving productivities. There is surely a strong correlation between GDP per unit of factor and factor prices that may not be solely the result of differences in productivity. Thus, Trefler's claim of strong support for the standard HOV model is questionable unless factor productivities are estimated appropriately.

In this paper we introduce a different approach to estimate factor-specific productivities based solely on a constant returns to scale (CRS) production function. ${ }^{3}$ This methodology permits extending Trefler's approach to HOV testing without facing the argument made by Gabaix. Using a newly constructed dataset covering 29 countries, we find evidence for the notion of basic factor-augmenting technology differences. Moreover, incorporating estimated

\footnotetext{
${ }^{3}$ Our approach builds on those of Davis and Weinstein (2001) and Maskus and Webster (1999). Maskus and Webster (1999) were concerned with ranking endowments across the United States and the United Kingdom, assuming the HOV model to be valid, rather than testing the trade model itself.
} 
factor productivities raises the fit of the standard HOV signs test from 46.6 percent to 72.4 percent and increases the variance ratio from 0.024 to 0.436 .

More fundamentally, we also find that the estimated productivities are strongly correlated with aggregate factor abundance in a relative sense. For example, workers in Japan, which is capital abundant, are productive (relative to Japanese capital) because they have access to machines and computers that make them efficient. This systematic correlation between laborproductivity and capital-abundance, which is consistent with general principles of the factorproportions model of trade without FPE, was previously discussed by Dollar, Wolff, and Baumol (1988).

Moreover, the idea of factor-specific productivity is strongly related to the literature on skill-biased technological change (Krusell, et al, 2000; Caselli and Coleman II, 2006). Because the rapid growth of physical capital interacts differently with different types of labor, capital productivity and labor productivity evolve differently with the stages of economic development. In particular, capital-skill complementarity could play a key role because the efficient operation of highly productive capital in developed countries requires skilled labor. ${ }^{4}$ Its importance here is that the empirical success of Trefler's basic model can be attributable to systematic productivity differences across factors that cannot be obtained from the Hicks-neutral form. Thus, similar to Davis and Weinstein (2001) who adjusted national technologies according to factor abundance, our results also indicate the important link between technology, productivity, and factor abundance. ${ }^{5}$ However, rather than general technology differences we consider only factor-

\footnotetext{
${ }^{4}$ Krusell, et al (2000) defined capital-skill complementarity as the situation where the elasticity of substitution between capital and unskilled labor is higher than that between capital and skilled labor. In this paper, using the data from Trefler (1993), we show that skilled-labor productivity and capital productivity co-move with economic development but these productivities move differently from unskilled-labor productivity.

${ }^{5}$ Davis and Weinstein relied on the Dornbusch, Fischer, and Samuelson (1980) model and Helpman's (1999) multiple-cone model of specialization to motivate this correlation.
} 
augmenting, industry-neutral productivity variations. This more restricted specification achieves considerable success for HOV.

Our finding points out a potential danger in applying strict HOV-type models in a relative (i.e., bilateral) sense because factor productivity interacts systematically with factor abundance. For example, Debaere (2003) demonstrated that the HOV equation holds better for South-North country pairs than for North-North country pairs. But this finding raises the question of whether South-North factor-productivity gaps or South-North factor-abundance differences drive support for the factor contents of trade. In fact, we show that the likely reason Debaere found strong evidence only for South-North country pairs of particular factor combinations is systematic South-North differences in factor productivity. Because the abundant factor (unskilled labor) has limited access to capital in the South, its labor productivities are systematically lower than those of capital. However, Northern data do not entail this feature. This productivity gap makes it hard to conclude that the success of the relative factor-abundance model is purely derived from South-North differences in adjusted factor endowments. Rather, both differences in factor productivities and factor endowments are responsible, with the balance of each element being unclear.

Our analysis lies within the HOV framework of incomplete specialization adjusted for productivity differences. It does not test for the possibility of multiple specialization cones that can arise due to large endowment differences (Debaere and Demiroglu, 2003; Schott, 2003). While we do not dispute that possibility, our primary concern is to analyze whether a straightforward specification of technological differences, appropriately estimated, can achieve a significant improvement in HOV performance. Thus, in contrast to the complicated 
specifications in Davis and Weinstein (2001), we find that the HOV equation performs well with the simple correction of factor-augmenting productivity.

In addition, Schott (2003) argues that the standard use in HOV testing of U.S. technologies for all countries suppresses evidence of specialization. Here we incorporate consistent technology matrices from many countries and discover evidence supporting the extended HOV model, suggesting that the bias he mentions may not be significant at the industry level. Moreover, this dataset avoids some of the problems in data construction facing those authors. For example, Debaere and Demiroglu (2003) incorporate factor prices as proxies for productivity differences, but this procedure is likely to overstate those variations. We directly estimate these variables from international technology data.

We organize the paper as follows. In Section 2 we revisit Trefler's (1993) model and the criticism in Gabaix (1997). In Section 3 we set out our empirical results from the estimation of factor-augmenting productivities and relate them to Trefler's approach. In addition, we study the characteristics of estimated productivities, particularly the correlation between productivity and factor abundance. In section 4 we examine the potential biases from ignoring factor productivities in the context of Debaere's (2003) relative factor-abundance model. Concluding remarks are offered in the final section.

\section{The HOV Model and Factor-Augmenting Productivity}

We begin by deriving the basic HOV prediction in a world with $F$ factors, $C$ countries, and $N$ products (sectors). Assume that all countries have identical constant returns to scale production technology; markets for goods and factors are perfectly competitive; there are no barriers to trade and zero transportation cost; factors move freely within a country but do not 
move across countries; and the distribution of factors is consistent with integrated equilibrium so that factor prices are equalized across countries.

For each country $c$ the net-export vector can be obtained as the difference between net production and the final consumption:

$$
\mathbf{T}_{c}=\left(\mathbf{I}-\mathbf{B}_{c}\right) \mathbf{Q}_{c}-\mathbf{C}_{c}
$$

where $\mathrm{T}_{\mathrm{c}}$ is an $N \times 1$ vector of net exports, $\mathrm{Q}_{\mathrm{c}}$ is an $N \times 1$ vector of gross output, and $\mathrm{C}_{\mathrm{c}}$ is an $N \times 1$ vector of final consumption. $\mathrm{B}_{\mathrm{c}}$ is an $N \times N$ input-output (indirect) matrix for the unit intermediate requirements so that $\left(I-B_{c}\right) Q_{c}$ equals the net output vector $Y_{c}$.

Let $\mathrm{A}_{\mathrm{c}}$ be the $F \times N$ direct technology matrix and its elements $\left(a^{\prime}{ }_{\text {cif }}\right)$ represent the amount of a factor needed to produce one unit of gross output in sector $i$. Pre-multiplying equation (1) by direct and indirect technology matrix $\mathrm{A}_{\mathrm{c}}\left(\mathrm{I}-\mathrm{B}_{\mathrm{c}}\right)^{-1}$, and applying the factor-exhaustion assumption $\mathrm{A}_{\mathrm{c}} \mathrm{Q}_{\mathrm{c}}=\mathrm{V}_{\mathrm{c}}$ where $\mathrm{V}_{\mathrm{c}}$ is an $F \times 1$ vector of factor endowments, we have that a country's factor contents of trade are the difference between factors absorbed in production $\left(\mathrm{A}_{c} \mathrm{Q}_{\mathrm{c}}=\mathrm{V}_{\mathrm{c}}\right)$ and factors absorbed in final consumption $\left(\mathrm{A}_{\mathrm{c}}\left(\mathrm{I}-\mathrm{B}_{\mathrm{c}}\right)^{-1} \mathrm{C}_{\mathrm{c}}\right)$ :

$$
\mathbf{A}_{c}\left(\mathbf{I}-\mathbf{B}_{c}\right)^{-1} \mathbf{T}_{c}=\mathbf{V}_{c}-\mathbf{A}_{c}\left(\mathbf{I}-\mathbf{B}_{c}\right)^{-1} \mathbf{C}_{c}
$$

Assuming identical and homothetic preferences, along with identical prices of goods and services, the final consumption vector is proportional to the world net output vector $\left(\mathrm{Y}_{\mathrm{w}}\right)$ :

$$
\mathbf{C}_{c}=s_{c} \mathbf{Y}_{W}
$$

where $s_{c}$ is a scalar representing the share of country $c$ in world expenditure. Because the production technology is identical worldwide and there is FPE, the technologies of the United States may be used to derive the following standard HOV equation:

$$
\mathbf{F}_{c}=\mathbf{V}_{c}-s_{c} \mathbf{V}_{W}
$$


where $F_{c}=A_{U S}\left(I-B_{U S}\right)^{-1} T_{c}$ is measured factor contents of trade with U.S. technologies and $V_{c^{-}}$ $s_{c} \mathrm{~V}_{\mathrm{w}}$ is predicted factor contents of trade. ${ }^{6}$ Thus, the HOV model tells us that measured factor contents of trade for any country can be predicted by that country's factor endowments, world factor endowments, and final consumption shares.

To integrate factor productivity into the HOV model, Trefler (1993) introduced coefficients $\left(\pi_{c f}\right)$ with the interpretation that if $V_{c f}$ is the factor endowment of country $c$ then $V_{c f}^{*}=\pi_{c f} V_{c f}$ is the corresponding factor endowment measured in productivity-equivalent units. Let $w_{c f}$ be the price per unit of $V_{c f}$ and let $w^{*}{ }_{c f}$ be the price per unit of $V_{c f}^{*}$. Since one unit of $V_{c f}$ provides $\pi_{c f}$ productivity-equivalent units of service, $1 / \pi_{c f}$ units of $V_{c f}$ provide one productivityequivalent unit service priced at $w^{*}{ }_{c f}=w_{c f} / \pi_{c f}$. Assuming identical technologies at the productivity-equivalent level and normalizing factor productivities of the United States to unity, we have this system of equations:

$$
\begin{gathered}
F_{c f}=\pi_{c f} V_{c f}-s_{c} \sum_{g=1}^{G} \pi_{g f} V_{g f} \\
w_{c f} / \pi_{c f}=w_{U S f} / \pi_{U S f} \Leftrightarrow w_{c f} / w_{U S f}=\pi_{c f} / \pi_{U S f}
\end{gathered}
$$

where equations (5) capture the elements of $\mathrm{F}_{\mathrm{c}}=\mathrm{A}_{\mathrm{US}}\left(\mathrm{I}-\mathrm{B}_{\mathrm{US}}\right)^{-1} \mathrm{~T}_{\mathrm{c}}, \pi_{U S f}=1$, and $g$ is the index of countries in the dataset.

\section{A. Trefler's Derivation of Factor-Productivity}

Trefler (1993) built the extended HOV model, adjusted by factor productivities, with the system of equations (5) and (6), using a dataset for 33 countries. Equation (5) is the HOV model with productivity-equivalent factors and equation (6) indicates that FPE holds when international factor productivities are adjusted. To estimate factor productivities $\left(\pi_{c f}\right)$, Trefler derived equation (7) from equation (5):

\footnotetext{
${ }^{6}$ To focus on predictions from the restrictive HOV model, we use U.S. technology to obtain measured factor contents of trade throughout this paper.
} 
(7) $\mathbf{F}_{f}=\mathbf{X}_{f} \boldsymbol{\Pi}_{f}$ where $\mathbf{F}_{f}=\left[\begin{array}{c}F_{1 f} \\ F_{2 f} \\ \vdots \\ F_{C f}\end{array}\right], \mathbf{X}_{f}=\left[\begin{array}{cccc}\left(1-s_{1}\right) V_{1 f} & -S_{1} V_{2 f} & \cdots & -s_{1} V_{C f} \\ -s_{2} V_{1 f} & \left(1-s_{2}\right) V_{2 f} & \cdots & -s_{2} V_{C f} \\ \vdots & \vdots & \ddots & \vdots \\ -s_{C} V_{1 f} & -s_{C} V_{2 f} & \cdots & \left(1-s_{C}\right) V_{C f}\end{array}\right], \boldsymbol{\Pi}_{f}=\left[\begin{array}{c}\pi_{1 f} \\ \pi_{2 f} \\ \vdots \\ \pi_{C f}\end{array}\right]$

Normalizing the productivities in terms of the United States, the $\pi_{c f}$ parameters may be estimated by ordinary least squares (OLS). However, once these estimated factor productivities are introduced into equation (5) it is inappropriate to apply standard testing procedures of the HOV model because fitted values for predicted factor contents of trade are identical to measured factor contents of trade. That is, all the HOV test statistics automatically would indicate a perfect fit.

To deal with this issue Trefler set out two methods to demonstrate the validity of his estimated factor productivities. One was to check the signs of the productivity parameters, with all expected to be positive. The other was to study the correlation between relative price ( $w_{c f}$ $\left./ w_{U S f}\right)$ and relative productivity $\left(\pi_{c f} / \pi_{U S f}\right)$ in equation (6) for each factor, with the correlation expected to be unity. Trefler noted that the productivities estimated from equation (7) were positive and that equation (6) performed well, with the correlation for labor being 0.90 and that for physical capital being 0.68 .

While the approach generated a number of comments, Gabaix (1997) in particular criticized this methodology for deriving the estimation method (equation (7)) testing factor productivities. His reasoning came from the "missing trade" phenomenon analyzed in Trefler (1995). Missing trade is the finding that measured factor contents of trade are generally very small relative to predicted factor contents of trade. Thus, if the vector of measured factor contents of trade were virtually zero in equation (5), we would have:

$$
0=\pi_{c f} V_{c f}-s_{c} V_{w f}^{*} \Leftrightarrow \pi_{c f}=s_{c} \frac{V_{w f}^{*}}{V_{c f}}=\frac{Y_{c}}{Y_{w}} \frac{V_{w f}^{*}}{V_{c f}}=\frac{Y_{c}}{V_{c f}} R
$$


where world aggregates $\left(V_{w f}^{*}=\Sigma_{g} \pi_{g f} V_{g f}\right.$ and $\left.R=V^{*}{ }_{w f} / Y_{w}\right)$ are essentially independent of the data from country $c$. In the case of labor, for example, the estimated productivity of labor would equal GDP per worker. Therefore, it is not surprising that Trefler's estimated productivities were positive and correlated strongly with factor prices. In this context, Trefler's approach offered no independent validation for the empirical success of his productivity modification of HOV.

Although Gabaix's criticism invalidates Trefler's methodology and statistical evidence, it does not necessarily mean the rejection of Trefler's model per se. Rather, if it were possible to estimate factor-productivity parameters independently of the equation system, incorporating them would not make HOV a truism and standard testing procedures would be valid. To this end, we develop unit total factor requirements $\left(a_{c i f}\right.$ is each element of total technologies $\left.\mathrm{A}_{c}\left(\mathrm{I}-\mathrm{B}_{c}\right)^{-1}\right)$ for each country and estimate factor productivities for each country across sectors. These estimated parameters are then incorporated to test equations (5) and (6). This procedure escapes the problems Gabaix (1997) pointed out.

\section{B. The Modified Approach}

Within Trefler's framework, countries share identical production technologies at the productivity-equivalent level, making adjusted unit factor requirements identical across countries for each factor: $a_{U S i f}=a^{*}$ cif for country $c$ and factor $f$ where $a_{c i f}{ }_{c i f}$ is $\pi_{c f} a_{c i f}$. If firms minimize unit cost functions with CRS technology, the quantity of factor $f$ required in sector $i$ for country $c$ divided by corresponding output is the unit factor requirement to produce one unit of gross output. Following Davis and Weinstein (2001), we estimate the productivity parameters by 
regressing the logarithm of unit factor requirements on country fixed effects and common unit factor requirements. ${ }^{7}$

We begin with Hicks-neutral productivity differences. With constant returns to scale, a single productivity $\left(\pi_{c}\right)$ augments each factor at the same rate $\left(V_{c L}^{*}=\pi_{c} V_{c L}\right.$ and $\left.V_{c K}^{*}=\pi_{c} V_{c K}\right)$. We estimate the following equation, which is the same as technology specification (P3) of Davis and Weinstein:

$$
\ln a_{c i f}=\theta_{c}+\ln \bar{a}_{i f}+\varepsilon_{c i f}
$$

where $\ln a_{c i f}$ is the $\log$ of measured unit factor requirements, $\ln \bar{a}_{i f}$ is the log of cross-country average unit factor requirements, and $\theta_{c}$ is a vector of coefficients on country dummies. A conventional measure of national total factor productivity (TFP) is then $\pi_{c}=1 / \exp \left(\theta_{c}\right)$. We normalize these coefficients so that the U.S. measure is equal to unity $\left(\pi_{U S}=1\right)$. Note that heteroskedasticity is likely to be present and so all technology regressions are weighted by $\bar{a}_{i f} \sqrt{\ln \left(V A_{c i}\right)} / \bar{a}_{f}$, where $V A_{c i}$ indicates value added, as in Davis and Weinstein (2001). ${ }^{8}$

We next consider the more general case of factor-augmenting productivity adjustments by allowing $\theta_{c f} \neq \theta_{c f}$ :

$$
\ln a_{c i f}=\theta_{c f}+\ln \bar{a}_{i f}+\varepsilon_{c i f}
$$

Here, $\left(1 / \exp \left(\theta_{c f}\right)\right)$ is consistent with Trefler's (1993) and Maskus and Nishioka's (2006) estimations of factor-augmenting productivity with the U.S. normalization. To compare the performance of equation (10) with various technology specifications with and without FPE in

\footnotetext{
${ }^{7}$ We also estimate factor-augmenting productivities, using the method of Maskus and Webster (1999), by regressing the unit factor requirements of the United States against those of each country across sectors. This approach confirmed that our results with Davis and Weinstein's technique are robust.

${ }^{8}$ Simple corrections with robust standard errors do not change the results of these estimations.
} 
Davis and Weinstein (2001), we also estimate their technology specifications (P4), (P5), and (P5') and present the results in Table 1. ${ }^{9}$

Table 1: Results of Technology Estimations

\begin{tabular}{|c|c|c|c|c|c|c|}
\hline & \multicolumn{4}{|c|}{ Specifications from Davis and Weinstein (2001) } & \multirow{2}{*}{\multicolumn{2}{|c|}{ Factor-augmenting Productivity }} \\
\hline & $\begin{array}{l}\text { Hicks-neutral } \\
\text { (P3) }\end{array}$ & $\begin{array}{c}\text { DFS with FPE } \\
\text { (P4) }\end{array}$ & $\begin{array}{c}\text { Helpman no-FPE } \\
\text { (P5) }\end{array}$ & $\begin{array}{c}\text { Unrestricted Helpman } \\
\text { no-FPE (P5') }\end{array}$ & & \\
\hline & Equation (9) & Equation (B-1) & Equation (B-2) & Equation (B-3) & \multicolumn{2}{|c|}{ Equation (10) } \\
\hline & Implied TFP & Implied TFP & Implied TFP & Implied TFP & Labor Productivity & Capital Productivity \\
\hline Australia & 0.782 & 0.782 & 0.783 & 0.776 & 0.719 & 0.852 \\
\hline Austria & 0.763 & 0.763 & 0.763 & 0.762 & 0.738 & 0.788 \\
\hline Belgium & 0.829 & 0.830 & 0.830 & 0.837 & 0.859 & 0.802 \\
\hline Brazil (D) & 0.561 & 0.554 & 0.556 & 0.492 & 0.233 & 1.312 \\
\hline Canada & 0.866 & 0.866 & 0.867 & 0.864 & 0.812 & 0.925 \\
\hline Czech Republic (D) & 0.609 & 0.607 & 0.609 & 0.578 & 0.415 & 0.889 \\
\hline Denmark & 0.858 & 0.857 & 0.858 & 0.851 & 0.760 & 0.966 \\
\hline Finland & 0.693 & 0.692 & 0.693 & 0.690 & 0.648 & 0.739 \\
\hline France & 0.870 & 0.870 & 0.869 & 0.875 & 0.854 & 0.885 \\
\hline Germany & 0.707 & 0.707 & 0.707 & 0.710 & 0.711 & 0.703 \\
\hline Greece (D) & 0.696 & 0.694 & 0.696 & 0.670 & 0.514 & 0.940 \\
\hline Hungary (D) & 0.606 & 0.603 & 0.606 & 0.566 & 0.371 & 0.982 \\
\hline Indonesia (D) & 0.526 & 0.517 & 0.525 & 0.451 & 0.211 & 1.291 \\
\hline Ireland & 0.828 & 0.826 & 0.828 & 0.805 & 0.707 & 0.963 \\
\hline Israel & 0.984 & 0.982 & 0.982 & 0.979 & 0.877 & 1.100 \\
\hline Italy & 0.836 & 0.836 & 0.836 & 0.835 & 0.834 & 0.837 \\
\hline Japan & 0.559 & 0.556 & 0.556 & 0.562 & 0.631 & 0.488 \\
\hline Korea (D) & 0.573 & 0.573 & 0.573 & 0.570 & 0.529 & 0.620 \\
\hline Netherlands & 0.797 & 0.797 & 0.798 & 0.792 & 0.712 & 0.892 \\
\hline New Zealand & 0.854 & 0.854 & 0.856 & 0.847 & 0.754 & 0.968 \\
\hline Norway & 0.821 & 0.824 & 0.824 & 0.831 & 0.736 & 0.919 \\
\hline Poland (D) & 0.608 & 0.605 & 0.609 & 0.554 & 0.310 & 1.186 \\
\hline Portugal (D) & 0.649 & 0.648 & 0.650 & 0.625 & 0.508 & 0.828 \\
\hline Slovak Republic (D) & 0.524 & 0.522 & 0.524 & 0.493 & 0.334 & 0.817 \\
\hline Spain & 0.745 & 0.745 & 0.745 & 0.737 & 0.694 & 0.799 \\
\hline Sweden & 0.797 & 0.796 & 0.797 & 0.785 & 0.727 & 0.873 \\
\hline Turkey (D) & 0.615 & 0.608 & 0.610 & 0.542 & 0.242 & 1.514 \\
\hline United Kingdom & 0.857 & 0.856 & 0.858 & 0.833 & 0.706 & 1.039 \\
\hline United States & 1.000 & 1.000 & 1.000 & 1.000 & 1.000 & 1.000 \\
\hline$\gamma_{\mathrm{KT}}$ & & $0.450(0.019)$ & $0.429(0.019)$ & & & \\
\hline$\gamma \mathrm{KN}$ & & & 0.560 & & & \\
\hline$\gamma_{\mathrm{LT}}$ & & $-0.450(-0.019)$ & $-0.472(-0.019)$ & & & \\
\hline$\gamma \mathrm{LN}$ & & & $-0.517(-0.021)$ & & & \\
\hline Obervations (T) & 1676 & 1676 & 1676 & 1676 & & 576 \\
\hline Parameters (k) & 86 & 87 & 89 & 137 & & 14 \\
\hline$-\log \mathrm{L}(\mathrm{LL})$ & -890 & -645 & -242 & -106 & & 18 \\
\hline SIC & 1.443 & 1.155 & 0.683 & 0.760 & & 766 \\
\hline $\mathrm{AIC}$ & 1.164 & 0.874 & 0.395 & 0.297 & & 397 \\
\hline
\end{tabular}

Notes: (1) Standard errors are reported in parentheses.

(2) Hicks-neutral and factor-augmenting productivities are estimated from $1 / \exp (\theta)$ with the normalization of U.S.=1

(3) There are 29 industries and 2 factors (sector 1 agriculture is dropped from the sample)

(4) The number of obervations is not 1,682 $(=29 * 29 * 2)$. We have to drop 6 observations of unit factor requirement (acif) because they are zeros.

(5) Developing countries (the South) are marked with (D). We sort countries by labor compensation per worker.

\footnotetext{
${ }^{9}$ In Appendix B we describe these specifications.
} 
Using the estimated factor-productivities from equation (10), we test both equations (5) and (6). This implicitly assumes that no other sources of international differences in unit factor requirements (technologies) exist after international factor productivities are adjusted. Because the factor-productivities are estimated solely from unit factor requirements, it is possible to examine equations (5) and (6) separately and apply standard testing procedures of the HOV model to equation (5). In addition, we can separately assess equation (6) in terms of the correlations between price and productivity for each factor.

In testing HOV we consider both the aggregate specification in (5) and the pair-wise HOV model (Staiger, Deardorff, and Stern, 1987; Hakura, 2001). The primary advantage of the pair-wise HOV model is that the testing equation does not include world aggregates. Because our dataset consists only of 29 countries, there is some question about data sums representing world aggregates. To derive the pair-wise model, apply equation (4) to two arbitrarily chosen countries. For example, take the ratio of the United States $(c=1)$ and Japan $(c=2)$ and cancel the net world output $\left(\mathrm{Y}_{\mathrm{w}}\right)$ in equation (3) $\left(\mathrm{C}_{1}=s_{1} / s_{2} \mathrm{C}_{2}=\alpha \mathrm{C}_{2}\right)$. Then, with appropriate subtraction, the pair-wise HOV model follows:

$$
\mathbf{F}_{1}-\alpha \mathbf{F}_{2}=\mathbf{V}_{1}-\alpha \mathbf{V}_{2}
$$

where $F_{1}-\alpha F_{2}$ is the measured relative factor contents of trade with U.S. technology $\left(F_{1}=A_{U S}(I-\right.$ $\left.B_{U S}\right)^{-1} T_{1}$ and $\left.F_{2}=A_{U S}\left(I-B_{U S}\right)^{-1} T_{2}\right)$ and $V_{1}-\alpha V_{2}$ is the predicted relative factor content of trade. ${ }^{10}$

Using equations (10) and (11), the pair-wise HOV model with factor-productivity adjustment follows:

$$
\mathbf{F}_{1}-\alpha \mathbf{F}_{2}=\boldsymbol{\Pi}_{1} \mathbf{V}_{1}-\alpha \mathbf{\Pi}_{2} \mathbf{V}_{2}
$$

\footnotetext{
${ }^{10}$ This specification is more restrictive than that in Hakura (2001) because she used each country's actual technology to measure factor contents of trade.
} 
Here $\Pi_{1}$ is a diagonal $\mathrm{F} \times \mathrm{F}$ matrix with elements that are the corresponding productivity coefficients of country $c\left(\pi_{c f}\right)$ estimated from equation (10). Note that the measured relative factor contents of trade in the pair-wise model do not change due to the introduction of factoraugmenting productivity adjustments. Testing procedures are the same as for the basic HOV model.

\section{Data and Empirical Results}

Estimating factor-productivity parameters from equation (10) requires data on actual technologies for multiple countries. Thus, we assembled a comprehensive dataset for a group of 29 countries in the year 2000 as described in Appendix A. There are two factors (physical capital and aggregate labor) and 30 industrial sectors. The dataset is similar to that in Davis and Weinstein (2001), who developed a 35-sector dataset of 10 advanced members of OECD. However, our data spans both developed and developing countries, with 19 being in the former category according to our sorting procedure. ${ }^{11}$

\section{A. Factor-Augmenting Productivity Estimates}

The final two columns of Table 1 report the estimated factor-productivity parameters and associated statistics for equation (10), where factor efficiencies are defined relative to the United States. All coefficients measuring factor productivities are positive and statistically significant at the one-percent level. The coefficients on aggregate labor for all 29 countries are lower than unity, suggesting that the United States has the highest levels of labor productivity. Regarding physical capital, some developing countries (Brazil, Indonesia, Poland and Turkey) and some developed countries (Israel and the United Kingdom) are more productive than those in the United States.

\footnotetext{
${ }^{11}$ Country names may be found in Table 1 . We sort the countries according to labor compensation per worker (average wage). Countries with average wage less than \$20,000 U.S. dollars (2000, PPP) are developing countries.
} 
For comparison purposes, the first four columns present national TFP estimates using equation (9) of this paper and various technology specifications in Davis and Weinstein (2001). According to the Schwarz Information Criteria (SIC), ${ }^{12}$ the technology estimation with factoraugmenting productivity adjustment is better than those with Hicks-neutral productivity adjustment (equation (9)) and with Dornbusch-Fischer-Samuelson technology adjustment (equation (B-1)) but is slightly worse than those with Helpman's specifications without FPE (equations (B-2) and (B-3)). Thus, for estimating technology differences our factor-productivity adjustment performs at least as well as Davis and Weinstein's successful specifications.

It is also of interest to compare the national factor-productivity parameters developed using Trefler's (1993) method (equation (7)) and those using our method in equation (10). In Table 2 we list the parameters computed from Table 1 (the final two columns) and those in Trefler's paper (the next pair of columns). The correlations between the corresponding factors are very high, at 0.830 for physical capital and 0.987 for aggregate labor. Thus, Trefler's estimated factor-productivities are very similar to those obtained from estimation based only on unit factor requirements.

In addition, we compare these factor productivities with our TFP estimates from equation (9) in the initial column of Table 1. The correlation between TFP and our estimated laboraugmenting productivity is very high $(0.894)$ but there is no correlation between TFP and capital productivity. In addition, the values of TFP generally lie between those for capital and labor. This would suggest that the empirical success of the factor-productivity adjustments in Trefler (1993) is attributable to systematic productivity differences across factors that the Hicks-neutral

\footnotetext{
${ }^{12} \mathrm{SIC}=-2(L L) /(T)+k \ln (T) / T$ where $L L$ is the log likelihood, $T$ is the observation, and $k$ is the number of independent variables.
} 
Table 2: Estimated Factor-Augmenting Productivity

\begin{tabular}{|c|c|c|c|c|c|}
\hline & \multicolumn{2}{|c|}{ Maskus and Nishioka (2008) } & \multicolumn{2}{|c|}{ Trefler (1993) } & \multirow{2}{*}{$\begin{array}{c}\text { TFP } \\
(5)\end{array}$} \\
\hline & (1) Labor & (2) Capital & (3) Labor & (4) Capital & \\
\hline Australia & 0.719 & 0.852 & 0.729 & 0.907 & 0.782 \\
\hline Austria & 0.738 & 0.788 & 0.720 & 0.777 & 0.763 \\
\hline Belgium & 0.859 & 0.802 & 0.865 & 0.800 & 0.829 \\
\hline Brazil (D) & 0.233 & 1.312 & 0.234 & 1.186 & 0.561 \\
\hline Canada & 0.812 & 0.925 & 0.784 & 0.882 & 0.866 \\
\hline Czech Republic (D) & 0.415 & 0.889 & 0.463 & 0.935 & 0.609 \\
\hline Denmark & 0.760 & 0.966 & 0.772 & 1.021 & 0.858 \\
\hline Finland & 0.648 & 0.739 & 0.699 & 0.838 & 0.693 \\
\hline France & 0.854 & 0.885 & 0.842 & 0.768 & 0.870 \\
\hline Germany & 0.711 & 0.703 & 0.728 & 0.671 & 0.707 \\
\hline Greece (D) & 0.514 & 0.940 & 0.595 & 1.065 & 0.696 \\
\hline Hungary (D) & 0.371 & 0.982 & 0.444 & 1.149 & 0.606 \\
\hline Indonesia (D) & 0.211 & 1.291 & 0.149 & 1.245 & 0.526 \\
\hline Ireland & 0.707 & 0.963 & 0.741 & 1.302 & 0.828 \\
\hline Israel & 0.877 & 1.100 & 0.916 & 1.102 & 0.984 \\
\hline Italy & 0.834 & 0.837 & 0.847 & 0.812 & 0.836 \\
\hline Japan & 0.631 & 0.488 & 0.642 & 0.547 & 0.559 \\
\hline Korea (D) & 0.529 & 0.620 & 0.524 & 0.529 & 0.573 \\
\hline Netherlands & 0.712 & 0.892 & 0.692 & 0.822 & 0.797 \\
\hline New Zealand & 0.754 & 0.968 & 0.811 & 1.117 & 0.854 \\
\hline Norway & 0.736 & 0.919 & 0.772 & 1.115 & 0.821 \\
\hline Poland (D) & 0.310 & 1.186 & 0.328 & 1.163 & 0.608 \\
\hline Portugal (D) & 0.508 & 0.828 & 0.500 & 0.895 & 0.649 \\
\hline Slovak Republic (D) & 0.334 & 0.817 & 0.407 & 1.069 & 0.524 \\
\hline Spain & 0.694 & 0.799 & 0.690 & 0.780 & 0.745 \\
\hline Sweden & 0.727 & 0.873 & 0.723 & 0.948 & 0.797 \\
\hline Turkey (D) & 0.242 & 1.514 & 0.283 & 1.262 & 0.615 \\
\hline United Kingdom & 0.706 & 1.039 & 0.674 & 1.026 & 0.857 \\
\hline United States & 1.000 & 1.000 & 1.000 & 1.000 & 1.000 \\
\hline (1) & 1.000 & -0.457 & 0.987 & -0.409 & 0.894 \\
\hline (2) & - & 1.000 & -0.468 & 0.830 & -0.037 \\
\hline correlations & - & - & 1.000 & -0.369 & 0.885 \\
\hline (4) & - & - & - & 1.000 & -0.009 \\
\hline$(5)$ & - & - & - & - & 1.000 \\
\hline
\end{tabular}

form (e.g., TFP) cannot account for. It also confirms previous findings in the literature that Hicks-neutral adjustments do not overturn failures of the HOV equation.

\section{B. Performance of the HOV Models}

Table 3 shows the results of testing the HOV model. The basic model, without factorproductivity adjustments, performs poorly as expected (Panel A). The sign fit is 46.6 percent for our two factors, the slope coefficient is 0.093 , and the variance ratio is 0.024 . Though the sign fit is marginally better than a coin-flip for a subset of developing countries, the slope and 


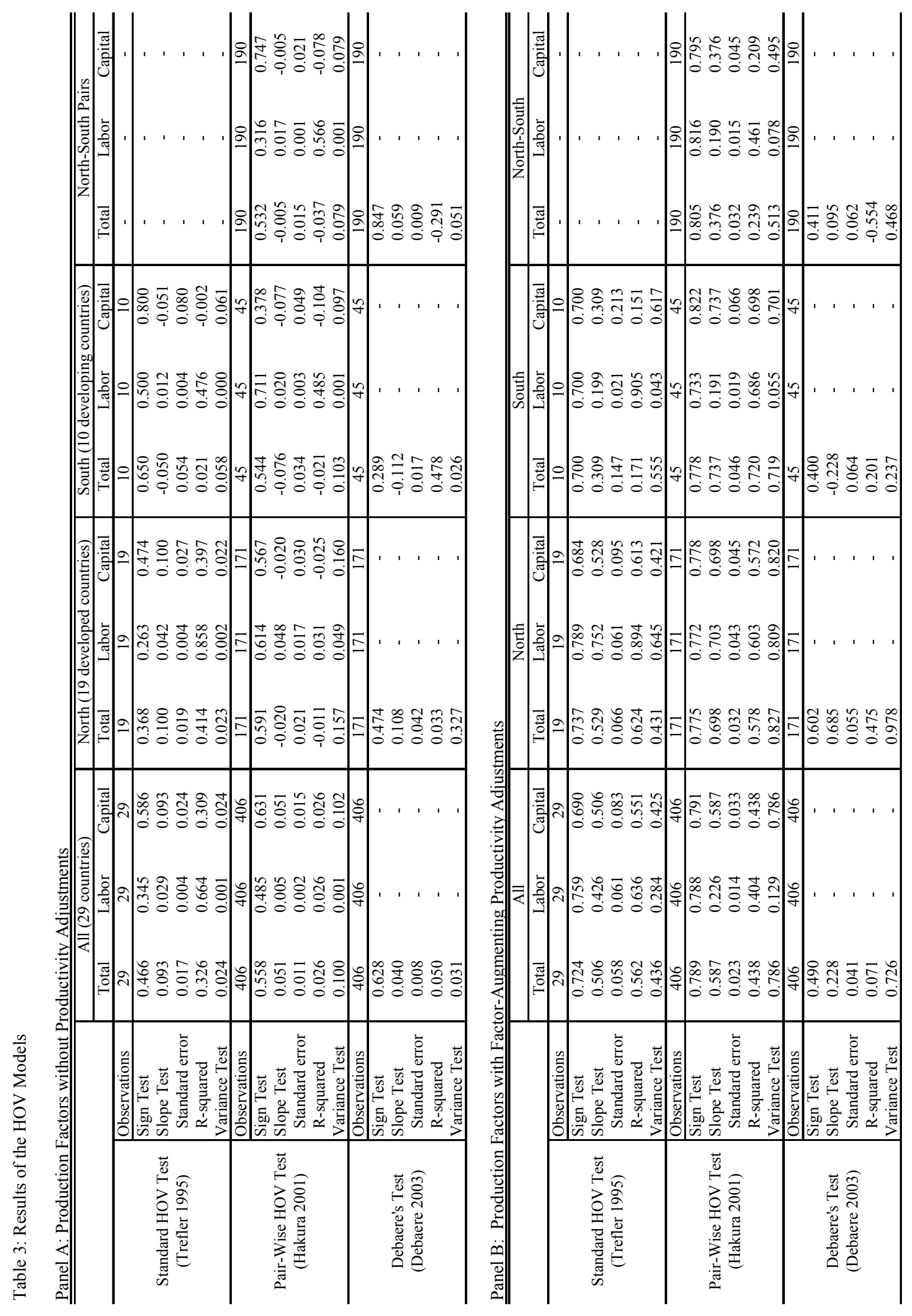


variance ratio tests indicate significant missing trade. The pair-wise tests do not achieve much better results. Neither is there a noticeable gain when a Hicks-neutral adjustment is added. ${ }^{13}$ Therefore, the results strongly reject both the standard and Hicks-neutral HOV models regardless of the level of economic development.

However, once the estimated factor productivities are introduced, these numbers improve considerably. For the standard HOV specification, as shown Panel B, the sign fit improves to 72.4 percent, the slope coefficient rises to 0.506 , and the variance ratio increases to 0.436 . The improvement for developed countries (the North) is particularly noteworthy. The sign test improves from 36.8 percent to 73.7 percent, the slope from 0.100 to 0.529 , and the variance ratio from 0.023 to 0.431 .

Regarding the pair-wise HOV model, Panel B also shows a considerable improvement when factor-productivity adjustments are incorporated. The sign test improves from 55.8 percent to 78.9 percent and the variance ratio improves from 0.100 to 0.786 . These positive improvements from the pair-wise models suggest that the effective performance of Trefler's factor-productivity adjustments was not simply spurious.

For further perspective, the correlation between factor productivities and factor prices as specified in equation (6) are very high, with the correlation for aggregate labor being 0.97 and that for physical capital being $0.74 .^{14}$

\section{C. Characteristics of Factor Productivity}

While introducing factor-productivity parameters $\left(\pi_{c f}\right)$ is a convenient method to modify the HOV model, their interpretation is not entirely clear. Suppose that workers in the United

\footnotetext{
${ }^{13}$ To conserve space we do not report these results but they are available upon request.

${ }^{14}$ We obtain the factor prices from total compensation for each factor divided by total amount of the corresponding factors. Compensation for physical capital is derived from gross operating surplus, which is net operation surplus plus consumption of fixed capital.
} 
States have the highest labor productivity. Then it could be that workers in the United States simply work harder than workers in other countries, ${ }^{15}$ American workers are no more industrious as workers elsewhere but they have access to technologies that make them more efficient, or the simple number of workers cannot account for the difference in each worker's efficiency occurring from educational attainment (i.e., the human-capital approach).

We are particularly interested in the second possibility, under which we expect that labor productivity correlates positively with capital abundance. ${ }^{16}$ This feature characterizes the data strongly between the developing countries and the developed countries, but weakly among the developed countries in an absolute sense. While the correlations between factor-augmenting productivity and the capital-labor ratio are -0.72 for capital and 0.89 for labor across all 29 countries, those among the developed countries are -0.54 and 0.24 , respectively. Using unadjusted input requirements, capital-productivities decline with capital abundance and labor productivities rise with capital abundance. One reason for these weak correlations among developed countries might be the limitation of our data to just two factors, with other elements such as knowledge capital and human capital being partially responsible for varying productivities.

However, when we incorporate the adjusted productivity ratios $\left(\pi_{c L} / \pi_{c K}\right)$, they correlate strongly with corresponding factor endowments as shown in Figure 1. For example, capitalabundant Japanese workers are productive relative to Japanese capital because they have access to abundant capital (machines and computers). It seems that Trefler's original explanation holds well in this "relative" sense. This observation suggests that, similar to the approach of Davis and

\footnotetext{
${ }^{15}$ It would be ideal to adjust the total number of employees by annual working hours. For most OECD countries such data are available but not for most developing countries. Once we adjust by annual working hours the labor productivities for most western European countries increase by 5-10 percent.

${ }^{16}$ This link was previously discussed by Dollar, Wolff, and Baumol (1988) who found a systematic correlation between labor productivity and capital abundance.
} 


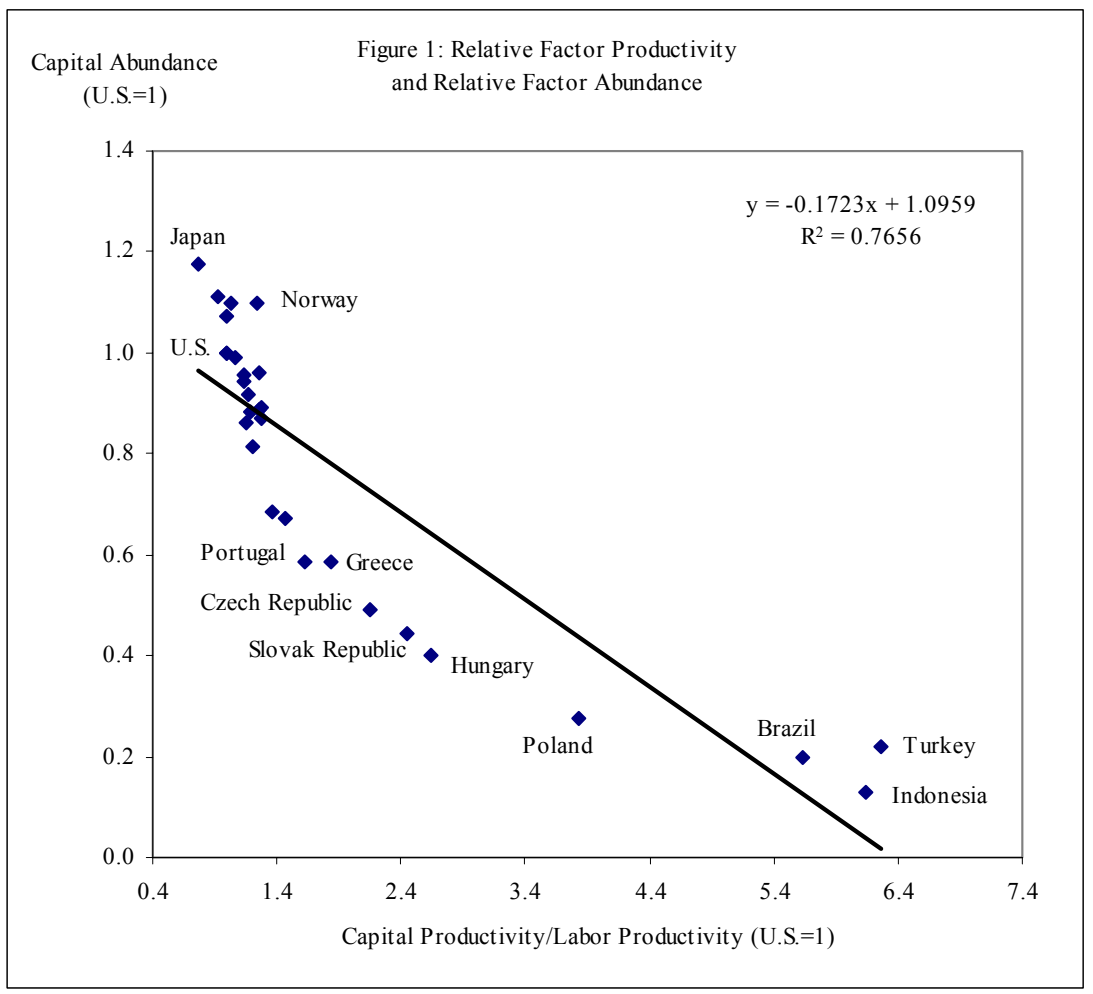

Weinstein (2001), who adjusted technologies according to factor abundance, our adjusted factor productivities also capture the link between technology, productivity, and factor-abundance that the Hicks-neutral form cannot accommodate.

\section{The Relative Factor Abundance Model and Factor Productivities}

The strong correlation between factor abundance and factor productivity is particularly relevant to the relative factor-abundance model of Debaere (2003). Debaere developed a prediction of the factor content of trade for the HOV model that relates bilateral differences in endowments to bilateral differences in factor trade. Our objective here is to reexamine his conclusion that, based on the sign test, the trade of South-North country pairs is consistent with HOV but that of North-North country pairs is not. We show that Debaere's result is caused not only by South-North differences in factor endowments, which is the issue he emphasized, but also by South-North differences in factor productivity. Specifically, because unskilled labor, the 
abundant factor in the South, has limited access to skilled labor and physical capital, the productivity of unskilled workers there is systematically lower than that in the North. This difference is an additional important reason that only South-North country-pairs perform well in his examination of HOV.

\section{A. Endowment-Related Productivity Biases}

To develop Debaere's relative factor abundance model, take equation (2) with U.S. technologies and impose identical and homothetic preferences:

$$
\mathbf{F}_{c}=\mathbf{V}_{c}-\mathbf{A}_{U S}\left(\mathbf{I}-\mathbf{B}_{U S}\right)^{-1} s_{c} \mathbf{Y}_{W}
$$

Divide both sides of equation (13) by the scalar expenditure share $s_{c}$ to obtain:

$$
\mathbf{F}^{*}{ }_{c}=\mathbf{V}^{*}{ }_{c}-\mathbf{A}_{U S}\left(\mathbf{I}-\mathbf{B}_{U S}\right)^{-1} \mathbf{Y}_{W}
$$

where $\mathrm{F}_{\mathrm{c}}=\mathrm{A}_{\mathrm{US}}\left(\mathrm{I}-\mathrm{B}_{\mathrm{US}}\right)^{-1} \mathrm{~T}_{\mathrm{c}}, \mathrm{F}^{*}{ }_{\mathrm{c}}=\mathrm{F}_{\mathrm{c}} / s_{c}$ and $\mathrm{V}_{\mathrm{c}}^{*}=\mathrm{V}_{\mathrm{c}} / s_{c}$. Now consider equation (14) for two countries, $c$ and $c^{\prime}$, and take the difference between their expressions:

$$
\mathbf{F}{ }_{c}^{*}-\mathbf{F}^{*}{ }_{c^{\prime}}=\mathbf{V}^{*}{ }_{c}-\mathbf{V}^{*}{ }_{c^{\prime}}
$$

Equation (15) may be expressed for a particular factor $(f)$ and divided by the sum of factor endowments, $V_{c f}^{*}+V_{c^{\prime} f}^{*}$ :

$$
\frac{F_{c f}^{*}-F_{c^{\prime} f}^{*}}{V_{c f}^{*}+V_{c^{\prime} f}^{*}}=\frac{V_{c f}^{*}-V_{c^{\prime} f}^{*}}{V_{c f}^{*}+V_{c^{\prime} f}^{*}}
$$

Then, express equation (16) for another factor $\left(f^{\prime}\right)$ and again take differences:

$$
\begin{aligned}
& \frac{F_{c f}^{*}-F_{c^{\prime} f}^{*}}{V_{c f}^{*}+V_{c^{\prime} f}^{*}}-\frac{F_{c f^{\prime}}^{*}-F_{c^{\prime} f^{\prime}}^{*}}{V_{c f^{\prime}}^{*}+V_{c^{\prime} f^{\prime}}^{*}}=\frac{V_{c f}^{*}-V_{c^{\prime} f}^{*}}{V_{c f}^{*}+V_{c^{\prime} f}^{*}}-\frac{V_{c f^{\prime}}^{*}-V_{c^{\prime} f^{\prime}}^{*}}{V_{c f^{\prime}}^{*}+V_{c^{\prime} f^{\prime}}^{*}} \\
& \Leftrightarrow \frac{F_{c f}^{*}-F_{c^{\prime} f}^{*}}{V_{c f}^{*}+V_{c^{\prime} f}^{*}}-\frac{F_{c^{\prime}}^{*}-F_{c^{\prime} f^{\prime}}^{*}}{V_{c^{\prime}}^{*}+V_{c^{\prime} f^{\prime}}^{*}}=\frac{2 V_{c^{\prime} f}^{*}}{V_{c^{\prime}}^{*}+V_{c^{\prime} f^{\prime}}^{*}}\left(\frac{V_{c^{\prime} f^{\prime}}^{*}}{V_{c^{\prime} f}^{*}}-\frac{V_{c f^{\prime}}^{*}+V_{c^{\prime} f^{\prime}}^{*}}{V_{c f^{\prime}}^{*}+V_{c^{\prime} f}^{*}}\right)
\end{aligned}
$$

Here, the relative difference in measured factor content of trade is on the left-hand side and the relative difference in predicted factor content of trade is on the right-hand side. 
For any two factors $f$ and $f^{\prime}$, a country $c$ is said to be relatively abundant in factor $f$ compared to country $c^{\prime}$ when $V_{c f}^{*} / V_{c f^{\prime}}^{*}$ is larger than $V_{c^{\prime} f}^{*} / V_{c^{\prime} f}^{*}$. This statement is easily shown because the relative factor abundance relationship $V_{c f}^{*} / V_{c f^{\prime}}^{*}>V_{c^{\prime} f}^{*} / V_{c^{\prime} f^{\prime}}^{*}$ holds if and only if $V_{c^{\prime} f^{\prime}}^{*} / V_{c^{\prime} f}^{*}>\left(V_{c f^{\prime}}^{*}+V_{c^{\prime} f}^{*}\right) /\left(V_{c f^{\prime}}^{*}+V_{c^{\prime} f}^{*}\right)$, which is the right-hand side of the second equation in (17). Therefore, the testing strategy is to check the sign concordance of measured and predicted relative differences in factor trade. ${ }^{17}$ Debaere showed that equation (17) holds for the case of Hicks-neutral productivity. We show in Appendix C that it holds also for the case of adjusted factor productivities.

Our tests using the 29-country dataset are reported in Table 3. As discussed in Debaere (2003), there are substantial differences in the performance of equation (17) for varying pairs of countries, depending on the stages of economic development. In particular, the sign match of country pairs when picking one North and one South is 84.7 percent, which is significantly better than the cases with North-North (47.4 percent) and South-South (28.9 percent). This finding is consistent with Debaere's basic result using either unadjusted or Hick-neutral-adjusted factor endowments and U.S. technology. However, as seen in Panel B, adjusting endowments by factor productivities makes a critical difference in the performance of the relative HOV model for pairs of developed countries. In those cases the sign match improves from 47.4 percent to 60.2 percent and the variance ratio improves from 0.327 to 0.978 . However, once factors are adjusted by our estimated factor productivities, these testing statistics for North-South pairs worsen significantly from 84.7 percent to 41.1 percent for the sign test, even though the variance ratio improves from 0.051 to 0.468 . The reduction in success of the sign test suggests implicitly that Debaere's finding was attributable, in an important degree, to productivity biases.

\footnotetext{
${ }^{17}$ Though Debaere (2003) reported only sign tests, we report slope tests and variance ratios as well.
} 
To explore further why the North-South pairs perform poorly under the relative HOV model with factor-augmenting productivity adjustments, we show that the relative factor abundance ratios $\left(V_{c f}^{*} / V_{c f^{\prime}}^{*}>V_{c^{\prime} f}^{*} / V_{c^{\prime} f}^{*}\right)$ in Debaere's model can be decomposed into two parts: (1) relative factor-productivity ratios; and (2) productivity-equivalent relative factor abundance. Denote factor endowments at the productivity-equivalent level as $V_{c f}^{\prime}=\pi_{c f} V_{c f}^{*}$ and rewrite relative factor abundance as:

$$
\frac{V_{c f}^{*}}{V_{c f^{\prime}}^{*}}>\frac{V_{c^{\prime} f}^{*}}{V_{c^{\prime} f^{\prime}}^{*}} \Leftrightarrow \frac{V_{c f}^{\prime} / \pi_{c f}}{V_{c f^{\prime}}^{\prime} / \pi_{c f^{\prime}}}>\frac{V_{c^{\prime} f}^{\prime} / \pi_{c^{\prime} f}}{V_{c^{\prime} f^{\prime}}^{\prime} / \pi_{c^{\prime} f^{\prime}}} \Leftrightarrow \frac{V_{c f}^{\prime}}{V_{c f^{\prime}}^{\prime}} \frac{\pi_{c f^{\prime}}}{\pi_{c f^{\prime}}}>\frac{V_{c^{\prime} f}^{\prime}}{V_{c^{\prime} f^{\prime}}^{\prime}} \frac{\pi_{c^{\prime} f^{\prime}}}{\pi_{c^{\prime} f}}
$$

Equation (18) explains that the relative factor-abundance ratio without productivity adjustments $\left(V_{c f}^{*} / V_{c f^{\prime}}^{*}\right.$ or $\left.V_{c f^{\prime} f}^{*} / V_{c f}^{*}\right)$ is the product of the productivity-equivalent relative factor abundance ratio $\left(V_{c f}^{\prime} / V_{c f^{\prime}}^{\prime}\right.$ or $\left.V_{c^{\prime} f}^{\prime} / V_{c^{\prime} f}^{\prime}\right)$ and the factor-productivity ratio $\left(\pi_{c f^{\prime}} / \pi_{c f}\right.$ or $\left.\pi_{c^{\prime} f} / \pi_{c^{\prime} f}\right)$. If, as Debaere assumed, the Hicks-neutral form $\left(\pi_{c f^{\prime}} / \pi_{c f}=\pi_{c^{\prime} f} / \pi_{c^{\prime} f}\right)$ is realistic, then relative factor abundance and productivity-equivalent factor abundance are identical and his basic conclusion holds. However, if productivity adjustments are more general, then both elements matter. For example, if $f$ is labor $(L)$ and $f^{\prime}$ is physical capital $(K)$ for the South $(c=S)$ and the North $\left(c^{\prime}=N\right)$, we might expect labor in the South to be less productive than in the North because it operates with a smaller relative capital endowment. As a result, we have an inequality in relative productivity ratios: $\pi_{S K} / \pi_{S L}>\pi_{N K} / \pi_{N L}$ or $\pi_{S K} / \pi_{N K}>\pi_{S L} / \pi_{N L}$. Here, inequality of the factorproductivity ratio might be the same as that of efficiency-adjusted factor abundance.

It is important, therefore, to study South-North differences in factor productivities in addition to relative factor endowments. For this purpose, using our 29-country dataset, we divide countries into the South and the North and develop the South-North productivity ratios for factors. These productivity figures for aggregate labor and physical capital are displayed in Figure 2.1, 2.2, and 2.3. If Hicks-neutral productivity differences were realistic, we would 
expect these ratios to be identical across any factor pair $\left(\pi_{c f^{\prime}} \pi_{c^{\prime} f^{\prime}}=\pi_{c f} / \pi_{c^{\prime} f}\right)$. However, while this tendency is evident in North-North pairs (Figure 2.1) it is not the case for North-South pairs (Figure 2.2). Rather, we find the interesting tendency that the productivity ratio of the South to the North for aggregate labor $\left(\pi_{S L} / \pi_{N L}\right)$ is nearly uniformly smaller than that for physical capital $\left(\pi_{S K} / \pi_{N K}\right)$. Regarding South-South comparisons (Figure 2.3) there is a negative relationship between relative factor productivities. Therefore, systematic tendencies in factor productivities support the inequality in equation (18) only for the South-North country pairs.

To conclude our analysis we investigate this issue using the same data as Debaere. Because his dataset is the same as that in Trefler (1993), it is not possible to estimate appropriate factor productivities by using bilateral simple regressions as in equation (10). Our compromise is to use Trefler's method in equation (7) to obtain factor productivities. We divide countries into the South and the North according to Debaere (2003), and develop the South-North productivity ratios for factors. The parameters $\left(\pi_{c f}\right)$ are obtained for physical capital, skilled labor, and unskilled labor. Similar to our previous results, we find that productivity ratios of the South to the North for unskilled labor are smaller than those for capital (Figure 3.4) and skilled labor (Figure 3.6). There is not a similar tendency for the North-North pairs of capital/skilled labor and unskilled labor/skill labor, nor for any country pairs of skilled labor/capital. Thus, the inequality in equation (18) is found in data only for the South-North country pairs of unskilled labor/skilled labor and unskilled labor/capital. ${ }^{18}$

In summary, the superior performance of the relative HOV model for North-South comparisons than for North-North and South-South pairs is mainly derived from these development-related biases in factor productivities. This evidence implies that Debaere's

\footnotetext{
${ }^{18}$ This same factor-productivity bias exists for the case of aggregate labor/capital in South-North pairs, but we do not report it here.
} 

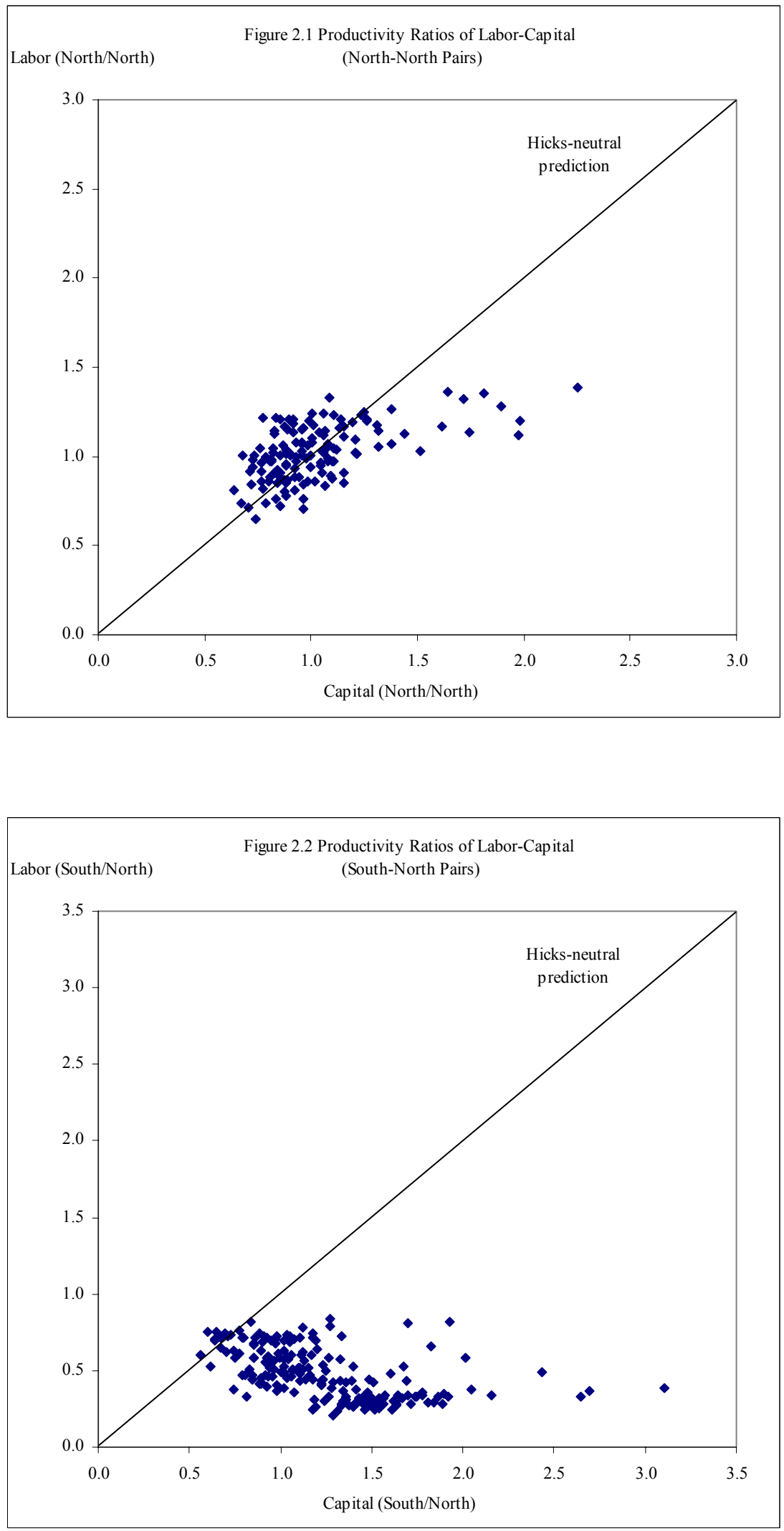


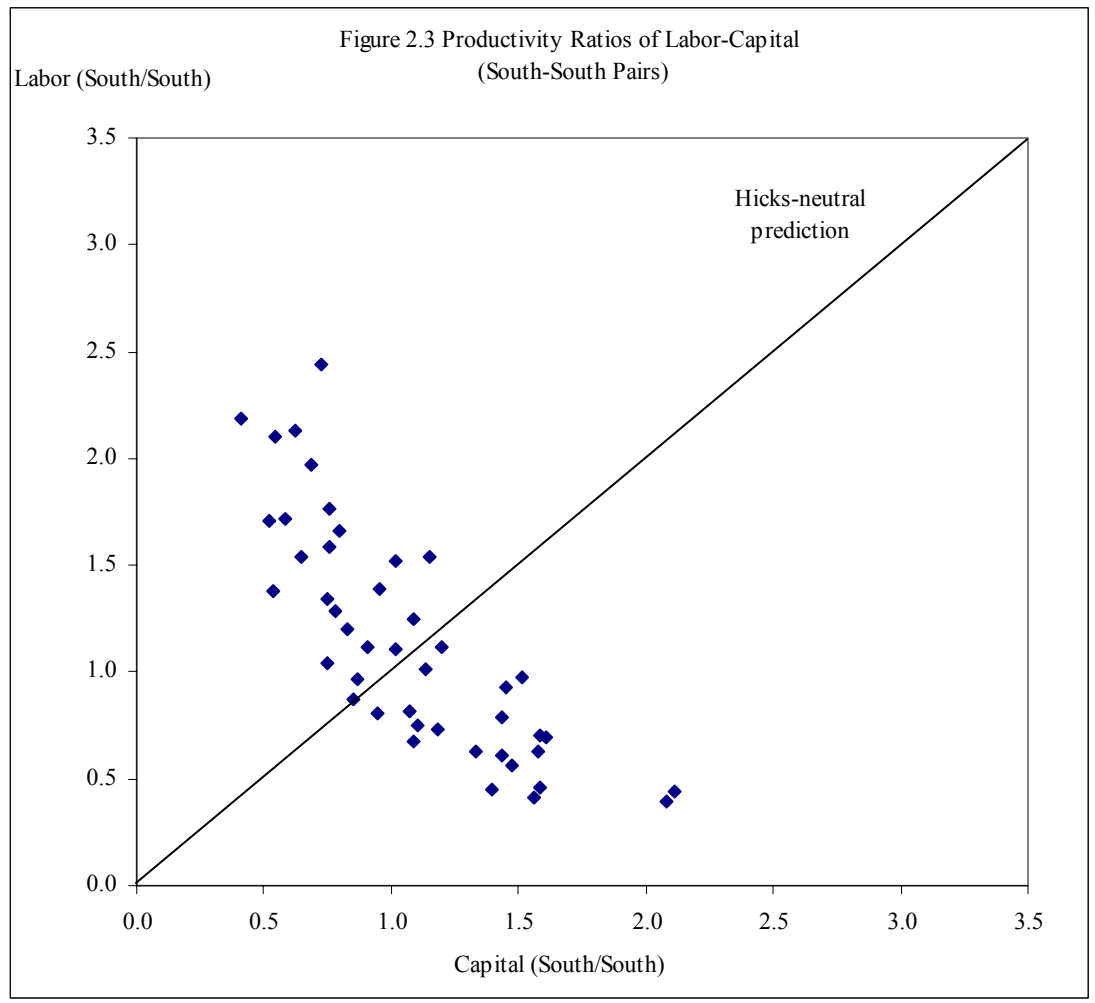

conclusion could be delivered by the interplay between endowment differences and factorproductivity differences.

\section{B. Relation to other Explanations of Productivity Biases}

Here we have attributed relative factor-productivity biases solely to differences in relative factor abundance. However, there are other possible sources of these biases. In particular, capital-skill complementarity (Krusell et al., 2000) and imperfect substitutability between skilled labor and unskilled labor (Caselli and Coleman II, 2006) have been cited as important possibilities. Regarding capital-skill complementarity, our analysis of Trefler's dataset unearths an implication similar to that of Krusell et al (2000). Specifically, capital productivity and skilled-labor productivity co-move with economic development. As seen in Figure 3.2, where most observations are in the lower left-hand corner, developing countries have lower relative productivity in both skilled labor and capital. In Figure 3.1, however, the observations are 
concentrated in the center, suggesting convergence of these productivities among the developed countries. If capital and skilled labor are complements, the higher productivity performance of skilled labor in the North might be associated with higher quality and sophistication of capital in the North. Our approach does not amount to a test of such complementarity, however.

On the other hand, as seen in Figures 3.4 and 3.6, the South's usage of unskilled labor is unproductive relative to the North's usage, regardless of the relative productivities of capital and skilled labor. This tendency of skill bias is quite different from the finding in Caselli and Coleman II (2006). ${ }^{19}$ They found evidence that developed countries use skilled labor more efficiently and developing countries use unskilled labor more efficiently. They explained this cross-country pattern of skill bias by imagining two different technologies to produce aggregate output. One is an assembly line where unskilled labor works with the supervision of just a few skilled workers. The other is a computer-controlled facility run solely by skilled workers while unskilled labor engages in janitorial work. They argue that the South chooses the first prototypical technology and the North chooses the second. Therefore, unskilled labor in the South is absolutely more productive.

We suggest two explanations why the dataset we use does not support this view, finding instead that unskilled labor is unproductive in the South. First, unskilled labor in Trefler's dataset consists of clerical, service, sales, agriculture, and production workers based on the International Standard Classification of Occupations. Therefore, Caselli and Coleman II's idea

\footnotetext{
${ }^{19}$ Strictly speaking, the calculation of factor productivities for Caselli and Coleman II (2006) is different from ours even though both assume constant return to scale production functions. Caselli and Coleman II estimated countrylevel production functions with a constant-elasticity-of-substitution (CES) aggregate of labor types: $y=K^{\alpha}\left[(\mathrm{AuLu})^{\sigma}\right.$ $\left.+(A s L s)^{\sigma}\right]^{(1-\alpha)} \sigma$ where $A u$ and $A s$ are factor-augmenting productivities for unskilled-labor and skilled-labor, respectively. They calibrated these productivities by introducing the condition that skill premium equals relative marginal products of skills: $w s / w u=(A s / A u)^{\sigma}(L s / L u)^{\left(\sigma^{-1)}\right.}$, and by using data measuring $L s, L u, w s / w u$, and parameters $\alpha=1 / 3,1 /(1-\sigma)=1.4$.
} 

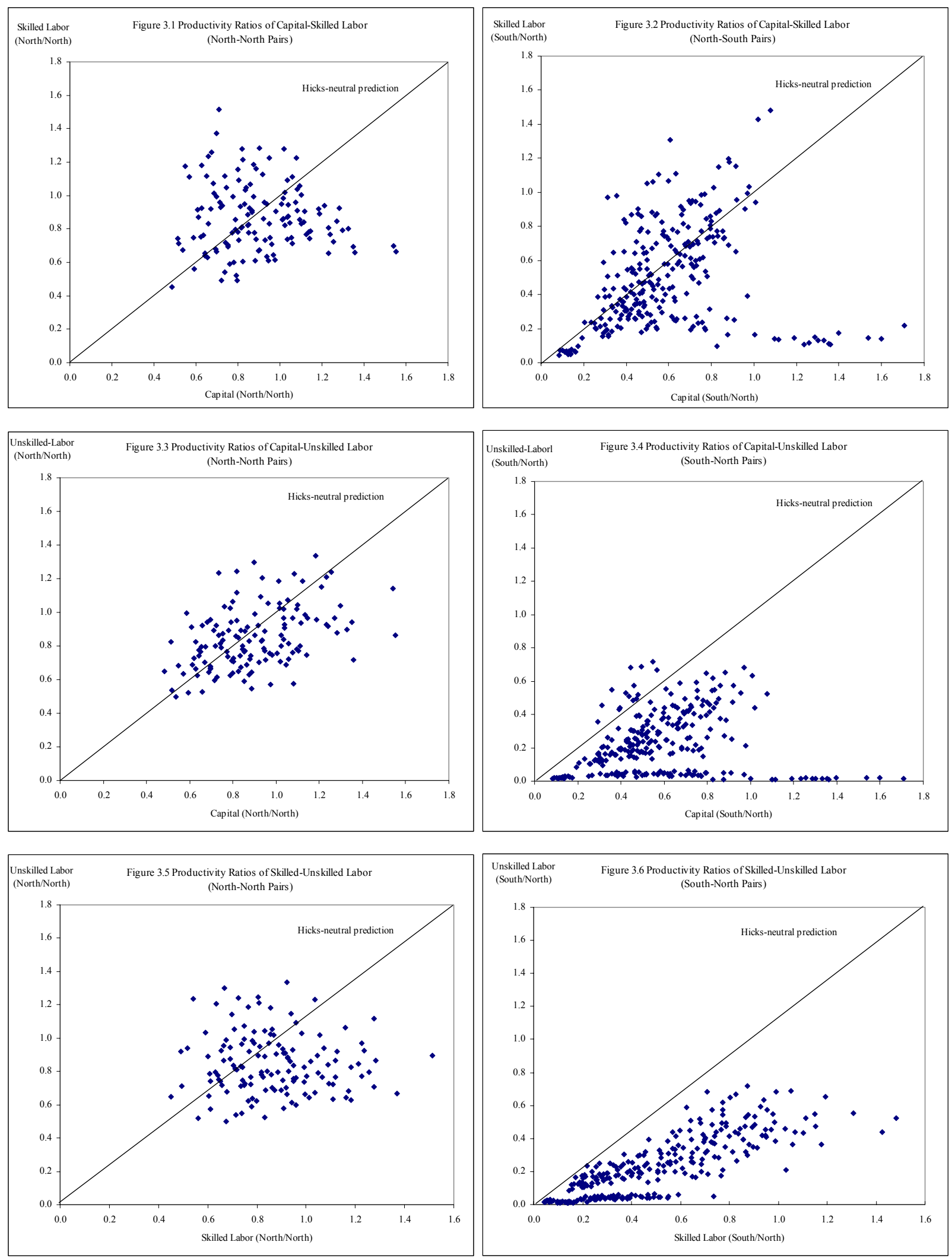
that unskilled workers operate solely as low-productivity support workers in the North is not applicable. As their preferred data show, their unskilled-labor measure amounts to less than three percent of skilled labor for the United States, indicating that unskilled workers are equivalent to the labor force that has virtually no educational achievement. Second, because of data limitations, we could not adjust Trefler's dataset to reflect international differences in educational attainment. Even in jobs for production facilities, workers with higher education might be employed in developed countries more than in developing countries. In contrast to the data we used, Caselli and Coleman II divided workers into skilled and unskilled labor from the categories of educational achievement set out by Barro and Jong-Wha Lee (2001). They weighted different types of education by relative wages so that the number of unskilled labor (skilled labor) is equivalent to that of no-education labor (workers completing primary education). Our inability to adjust for education (human capital) might affect our estimates of factor productivities based on occupational differences. Thus, a useful subject for future research would be to combine the data on detailed educational achievement and wages with the HOV equation.

\section{Concluding Remarks}

In this paper we reexamine Trefler's (1993) basic factor-productivity model. Departing from his procedure, we estimate factor-productivity parameters from each country's actual technologies. This approach permits use of the standard evaluations of the HOV model (sign test, slope test, and variance ratio test). Using a dataset of 29 countries, we find evidence supporting the fundamental idea of factor-augmenting productivities, with both the sign concordance and the variance ratio increasing markedly. Our results indicate that factor-augmenting productivity differences are an appropriate modification of HOV models. 
Prior studies that made technological specifications increasingly more flexible by using countryspecific data also supported the extended HOV model (Hakura, 2001; Davis and Weinstein, 2001). Indeed, Davis and Weinstein (2001) established a strong fit of the HOV equations when technologies are modified across both industries and countries according to factor abundance. The contribution here is to show that a simpler modification - factor augmentation that is neutral across industries - can establish considerable gains in the predictive performance of the HOV model. More fundamentally, the analysis unearthed a particular feature of factor productivities in both our 29-country data from the year 2000 and Trefler's earlier dataset. Specifically, factor productivities are inversely correlated with own-factor endowments and positively correlated with other factor endowments, which is consistent with the neoclassical trade model without FPE due, say, to specialization within different cones. This is especially the case as regards labor in developing countries. As a result, Debaere's (2003) finding that South-North factor trade may be explained well by the relative HOV model with Hicks-neutral productivity differences needs to be supplemented by the interplay between relative endowments and factor productivities.

\section{References}

Antweiler, Werner and Daniel Trefler (2002). "Increasing Returns and All That: A View from Trade," American Economic Review 92, pp 93-119.

Barro, Robert J. and Jong-Wha Lee (2001). "International Data on Educational Attainment: Updates and Implications," Oxford Economic Papers 53, pp 541-563.

Bowen, Harry P., Edward E. Leamer, and Leo Sveikauskas (1987). "Multicountry, Multifactor Tests of the Factor Abundance Theory," American Economic Review 77, pp 791-809.

Caselli, Francesco and Wilbur John Coleman II (2006). "The World Technology Frontier," American Economic Review 96, pp 499-522.

Davis, Donald R. and David E. Weinstein (2001). "An Account of Global Factor Trade," American Economic Review 91, pp 1423-1453. 
Davis, Donald R., David E. Weinstein, Scott C. Bradford, and Kazushige Shimpo (1997). "Using International and Japanese Regional Data to Determine When the Factor Abundance Theory of Trade Works," American Economic Review 87, pp 421-446.

Debaere, Peter (2003). "Relative Factor Abundance and Trade," Journal of Political Economy 111, pp 589-610.

Debaere, Peter and Ufuk Demiroglu (2003). "On the Similarity of Country Endowments," Journal of International Economics 59, pp 101-136.

Dollar, David, Edward N. Wolff, and William J. Baumol (1988). “The Factor-Price Equalization Model and Industry Labor Productivity: An Empirical Test across Countries," in Robert C. Feenstra, ed., Empirical Methods for International Trade. Cambridge, MA: MIT Press, pp 2347.

Dornbusch, Rudiger, Stanley Fischer, and Paul A. Samuelson (1980). "Heckscher-Ohlin Trade Theory with a Continuum of Goods," Quarterly Journal of Economics 95, pp 203-224.

Feenstra, Robert C. and Gordon H. Hanson (2000). "Aggregation Bias in the Factor Content of Trade: Evidence from U.S. Manufacturing," American Economic Review 90, pp 155-160.

Fitzgerald, Doireann and Juan Carlos Hallak (2004). "Specialization, Factor Accumulation and Development,” Journal of International Economics 64, pp 277-302.

Gabaix, Xavier (1997). "The Factor Content of Trade: A Rejection of the Heckscher-OhlinLeontief Hypothesis," Harvard University, Department of Economics, manuscript.

Hakura, Dalia S. (2001). "Why Does HOV Fail? The Role of Technological Differences within the EC," Journal of International Economics 54, pp 361-382.

Helpman, Elhanan (1999). "The Structure of Foreign Trade," Journal of Economic Perspectives 13 , pp 121-144.

Heston, Alan, Robert Summers, and Bettina Aten (2006). "Penn World Table Version 6.2," Center for International Comparisons of Production, Income and Prices at the University of Pennsylvania.

Keller, Wolfgang (2000). "Do Trade Patterns and Technology Flows Affect Productivity Growth?" World Bank Economic Review 14, pp 17-47.

Krusell, Per, Lee E. Ohanian, José-Víctor Ríos-Rull, and Giovanni L. Violante (2000). "CapitalSkill Complementarity and Inequality: A Macroeconomic Analysis," Econometrica 68, pp 10291053. 
Lai, Huiwen and Susan Chun Zhu (2007). "Technology, Endowments, and the Factor Content of Bilateral Trade," Journal of International Economics 71, pp 389-409.

Leamer, Edward E. (1984). Sources of International Comparative Advantage: Theory and Evidence, Cambridge, MA: MIT Press.

Leontief, Wassily (1953). "Domestic Production and Foreign Trade: The American Capital Position Re-examined," Proceedings of the American Philosophical Society 97, pp 332-349.

Maskus, Keith E (1985). "A Test of the Heckscher-Ohlin-Vanek Theorem: The Leontief Commonplace," Journal of International Economics 19, pp 201-212.

Maskus, Keith E. and Allan Webster (1999). "Estimating the HOV Model with Technology Differences Using Disaggregated Labor Skill for the United States and the United Kingdom," Review of International Economics 7, pp 8-19.

Maskus, Keith E. and Shuichiro Nishioka (2006). “ Development-Related Biases in Factor Productivities and the HOV Model of Trade," University of Colorado, Department of Economics, manuscript.

Schott, Peter K. (2003). "One Size Fits All? Heckscher-Ohlin Specialization in Global Production," American Economic Review 93, pp 686-708.

Staiger, Robert W., Alan V. Deardorff, and Robert M. Stern (1987). “An Evaluation of Factor Endowments and Protection as Determinants of Japanese and American Foreign Trade," Canadian Journal of Economics 20, pp 449-463.

Trefler, Daniel (1993). “International Factor Price Differences: Leontief was Right!” Journal of Political Economy 101, pp 961-987.

Trefler, Daniel (1995). "The Case of the Missing Trade and Other Mysteries," American Economic Review 85, pp 1029-1046.

\section{Appendix A: Construction of Data}

1) Input-Output Data

Input-output (I-O) tables (total use) for Australia (1998-1999), Austria (2000), Belgium

(2000), Brazil (2000), Canada (2000), Czech Republic (2000), Denmark (2000), Finland (2000),

France (2000), Germany (2000), Greece (1999), Hungary (2000), Indonesia (2000), Ireland

(1998), Israel (1995), Italy (2000), Japan (2000), Korea (2000), the Netherlands (2000), New 
Zealand (1995-1996), Norway (2001), Poland (2000), Portugal (1999), Slovak Republic (2000), Spain (2000), Sweden (2000), Turkey (1998), the United Kingdom (2000), and the United States (2000) are from the OECD input-output database for 2007. Four more countries (Argentina, China, India, and Taiwan) are available in the database but are excluded here, either because the data on gross operating surplus are unavailable (China and India) or there are no reliable factor input data sources across industries (Argentina and Taiwan).

The I-O tables from the OECD database employ ISIC Rev. 3 classification containing 48 industrial groups but some countries do not report all 48 industries. Rather than estimating these unreported data, we aggregate into 30 industries (Table A) so that industrial classification is consistent across countries. Aggregation is inevitable but raises the risk of systematic bias in the HOV predictions, a problem in all such studies (Feenstra and Hanson, 2000).

The number of industrial groups is smaller than the 35 sectors used by Davis and Weinstein (2001) but is greater than the 23 sectors used by Hakura (2001) and the 24 sectors used by Lai and Zhu (2007). The input-output matrices and final consumption, gross output, and net exports are derived from the I-O tables for the year 2000. Final consumption is the sum of final consumption of households, final consumption and investment of government, gross fixed capital formation, and changes in inventory. Therefore, the total use table of country $c$ always satisfies the equation: $T_{c}=\left(I-B_{c}\right) Q_{c}-C_{c}$ where $B_{c}$ is a $30 \times 30$ indirect technology matrix for the unit intermediate requirements and $\left(I-B_{c}\right) Q_{c}$ vector equals net output $\left(Y_{c}\right)$. $B_{c}$ is obtained by taking input-output data from the I-O tables and dividing inputs in each sector by the corresponding sector's gross output. ${ }^{20}$

\footnotetext{
${ }^{20}$ In the case of two sectors, the input usage matrix can be obtained as following.

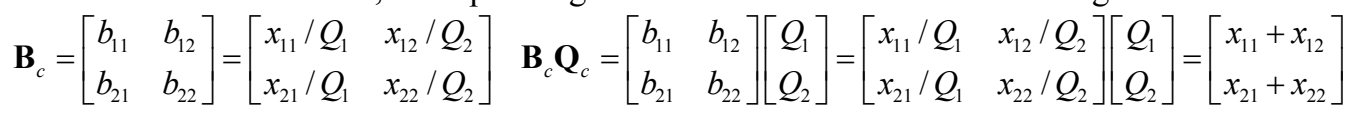


To convert the dataset into 2000 U.S. dollars with purchasing power parity (PPP) adjustments, we use GDP price deflators for 2000 from the Penn World Table version 6.2 (Heston et al, 2006) and average nominal exchange rates from the International Financial Statistics 2006 (IMF). For Australia, Greece, Ireland, Israel, New Zealand, Portugal, and Turkey, nominal values in the I-O tables are uniformly multiplied by the growth rates of total nominal GDP to adjust data from earlier years to the year 2000 .

Table A: Classification of Industrial Activities

\begin{tabular}{c|l|c}
\hline \hline sectors & \multicolumn{1}{|c|}{ Branches of Activities } & ISIC Rev.3 \\
\hline 1 & Agriculture, hunting, forestry, and fishing & $1-2,5$ \\
2 & Mining and quarrying & $10-14$ \\
3 & Food products and beverages & $15-16$ \\
4 & Textiles & $17-19$ \\
5 & Wood and of products of wood and cork & 20 \\
6 & Paper and paper products & $21-22$ \\
7 & Coke, refined petroleum products and nuclear fuel & 23 \\
8 & Chemicals and chemical products & 24 \\
9 & Rubber and plastics products & 25 \\
10 & Other non-metallic mineral products & 26 \\
11 & Basic metals & 27 \\
12 & Fabricated metal products & 28 \\
13 & Machinery and equipment & 29 \\
14 & Office, accounting and computing machinery & 30 \\
15 & Electrical machinery and apparatus & 31 \\
16 & Radio, television and communication equipment and apparatus & 32 \\
17 & Medical, precision and optical instruments & 33 \\
18 & Motor vehicles, trailers and semi-trailers & 34 \\
19 & Other transport equipment & 35 \\
20 & Other manufacturing (incuding recycling) & $36-37$ \\
21 & Electricity, gas and water supply & $40-41$ \\
22 & Construction & 45 \\
23 & Wholesale and retail trade & $50-52$ \\
24 & Hotels and restaurants & 55 \\
25 & Transport, storage and communications & $60-64$ \\
26 & Financial intermediation & $65-67$ \\
27 & Real estate, renting and business activities & $70-74$ \\
28 & Public administration and defence & 75 \\
29 & Education & 80 \\
30 & Health and social work & $85-93,95,99$ \\
\hline
\end{tabular}

\section{2) Factor Endowment Data}

\section{(A) Physical Capital Stock}

Capital stock is developed by the discounted sum of real gross fixed capital formation in 2000 PPP U.S. dollars $\left(G F C F_{c i t}\right)$ from 1980 to 2000. 


$$
K_{c i}=\sum_{t=1980}^{2000}(1-0.1333)^{2000-t} G F C F_{c i t}
$$

Because industry-level values for gross fixed capital formation are not stable over the period, we do not use the perpetual inventory method (e.g., Keller, 2000). For OECD countries, values for gross fixed capital formation (GFCF) are derived from the OECD structural analysis (STAN) database (2004) and unreported data are estimated from the ISIC Rev.2 version of the OECD STAN database (1998). As many GFCF data as possible are derived from these databases but there are still some unavailable values. The following procedure is taken to interpolate these data. First, some detailed sectors (e.g., 18 "Motor vehicles, trailers and semi-trailers" and 19 "Other transport equipment") are unavailable for certain years but data for their aggregated value $(18+19$ "Transport equipment") exist for all years. We use the share of the nearest year to allocate those totals to each detailed sector. Second, if a country reports only aggregated industry sub-totals (18+19 “Transport equipment"), we first develop capital stocks of these subtotals and allocate these values to each industry according to the compensation for capital (gross operating surplus) obtained from the I-O tables. This procedure is based on the idea that industry capital compensation flows are proportional to industry capital stocks (Lai and Zhu, 2007). In particular, for non-OECD countries (Brazil, Indonesia and Israel) and for Greece and Turkey, we develop country-level capital stock (gross fixed capital formation is derived from World Bank World Development Indicators and OECD STAN database) and allocate country totals to each industry according to capital compensation data from the I-O tables. Finally, unreported years of Czech Republic (1980-1994), Hungary (1980-1990), Poland (1980-1991), Portugal (1980-1994), and Slovak Republic (1980-1992) are interpolated with industry-level growth rates of available years. 
One major problem with using GFCF data from the OECD STAN database (2004) is that most countries include residential investments but three (Canada, the United Kingdom and the United States) do not. In particular, agriculture and real estate are the main sources of errors from residential investments. To avoid serious errors, we obtain the difference between values for gross fixed capital formation from the OECD STAN database and those from International Financial Statistics (IMF) for these three countries and add these differences into the real estate sector. Unfortunately, it is impossible to adjust agriculture for residential investment and caution must be exercised when data from that sector are used in the analysis.

To convert GFCF figures into real series, we convert values into nominal U.S. dollars, divide by the price of investment from the Penn World Table 6.2, and deflate by U.S. industrylevel prices for gross fixed capital formation, which is obtained from the OECD STAN database (2004). After this conversion into 2000 PPP U.S. dollars, we compute real capital stock data, using a depreciation rate of 0.1333 (e.g., Leamer, 1984; Bowen, Leamer, and Sveikauskas, 1987; and Davis and Weinstein, 2001). For Japan, industrial GFCF data are unavailable from the STAN database. Therefore, we take the total GFCF series from the World Development Indicators (World Bank) and Japan's sectoral shares are obtained from the nominal investment matrix tables of the ESRI-Histat database (ISIC Rev.3).

(B) Labor

Sectoral labor inputs (total employment) for the year 2000 are derived from the OECD STAN databases (1998 and 2004) and the ILO LABORSTA Internet Yearly Statistics (http://laborsta.ilo.org/). Most data are available from these sources. If a country reports only aggregated industry sub-totals, we allocate these to each industry according to the compensation of employees obtained from the I-O tables. For most OECD countries, country-level annual 
working hours are available from the OECD Employment and Labor Market Statistics (2006) and the OECD STAN database (2004) but it is not possible to obtain industry-level annual working hours. Even though the data on weekly and/or monthly working hours for all countries in our dataset except Indonesia are available from ILO LABORSTA Internet Yearly Statistics, the definition, classification, and coverage differ from country to country. Therefore, we do not adjust total number of employees by working hours.

\section{Appendix B: Technology Specifications in Davis and Weinstein (2001)}

Specification (P4) is based on the Dornbusch-Fischer-Samuelson (1980) model in which unit factor requirements for tradables are systematically correlated with country-level capital abundance:

$$
\ln a_{c i f}=\theta_{c}+\ln \bar{a}_{i f}+\gamma_{f}^{T} \ln \left(K_{c} / L_{c}\right) T_{i}+\varepsilon_{c i f}
$$

where $T_{i}$ is a dummy variable that takes on a value of one if the sector is tradable (agriculture, mining, and manufacturing sectors) and zero if the sector is non-traded goods. Here, we impose the restriction $\left(\Sigma_{f} \gamma_{f}^{T}=0\right)$ so that capital intensity does not affect the Hicks-neutral productivity $\left(\theta_{c}\right)$.

Specification (P5) derives from Helpman (1999), in which FPE fails and countries are in different production cones, affecting coefficients in both traded and non-traded goods:

$$
\ln a_{c i f}=\theta_{c}+\ln \bar{a}_{i f}+\gamma_{f}^{T} \ln \left(K_{c} / L_{c}\right) T_{i}+\gamma_{f}^{N} \ln \left(K_{c} / L_{c}\right)\left(1-T_{i}\right)+\varepsilon_{c i f}
$$

where we restrict parameters with $\Sigma_{f}\left(\gamma_{f}^{T}+\gamma^{N}\right)=0$.

Davis and Weinstein also consider a more general specification in which they do not force country capital-labor ratios to have the same effects across sectors. This is the unrestricted technology differences of Helpman (P5'): 


$$
\ln a_{c i f}=\theta_{c}+\ln \bar{a}_{i f}+\gamma_{i f} \ln \left(K_{c} / L_{c}\right)+\varepsilon_{c i f}
$$

\section{Appendix C: Relative Abundance and Factor-Productivity Adjustment}

Here we introduce factor-augmenting productivity to the right-hand side of equation (17).

First, in the following equation we show that the inequality in relative factor abundance for the factor-productivity model does not coincide with that for the strict (or Hicks-neutral) model.

Thus, the empirical prediction of Debaere's model with factor-productivity parameters differs from Debaere's original specification.

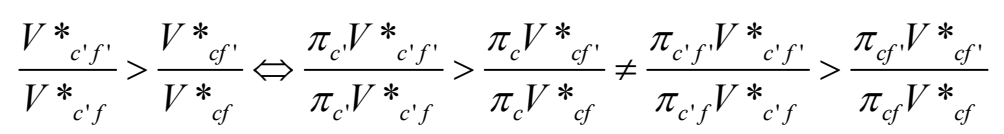

Proof of the relative factor-abundance model with factor-augmenting productivities follows.

$$
\begin{aligned}
& \frac{\pi_{c^{\prime} f^{\prime}} V_{c^{\prime} f^{\prime}}^{*}}{\pi_{c^{\prime} f} V_{c^{\prime} f}^{*}}>\frac{\pi_{c f^{\prime}} V_{c f^{\prime}}^{*}}{\pi_{c f} V_{c f}^{*}} \Leftrightarrow \quad \pi_{c^{\prime} f^{\prime}} V_{c^{\prime} f^{\prime}}^{*} \pi_{c f} V_{c f}^{*}>\pi_{c f^{\prime}} V^{*}{ }_{c f^{\prime}}, \pi_{c^{\prime} f} V_{c^{\prime} f}^{*} \\
& \Leftrightarrow \begin{array}{l}
\pi_{c^{\prime} f} V_{c^{\prime} f^{\prime}}^{*} \pi_{c f} V_{c f}^{*}+\pi_{c^{\prime} f} V_{c^{\prime} f^{\prime}}^{*} \pi_{c^{\prime} f} V_{c^{\prime} f}^{*} \\
>\pi_{c f^{\prime}} V_{f^{\prime}}^{*} \pi_{c^{\prime} f} V_{c^{\prime} f}^{*}+\pi_{c^{\prime} f} V_{c^{\prime} f^{\prime}}^{*} \pi_{c^{\prime} f} V_{c^{\prime} f}^{*}
\end{array} \\
& \Leftrightarrow \quad \frac{\pi_{c^{\prime} f^{\prime}} V_{c^{\prime} f^{\prime}}^{*}\left(\pi_{c f} V_{c f}^{*}+\pi_{c^{\prime} f} V_{c^{\prime} f}^{*}\right)}{\pi_{c^{\prime} f} V_{c^{\prime} f}^{*}\left(\pi_{c f^{\prime}} V_{c f^{\prime}}^{*}+\pi_{c^{\prime} f^{\prime}} V_{c^{\prime} f^{\prime}}^{*}\right)}>1 \\
& \Leftrightarrow \quad \frac{\pi_{c^{\prime} f^{\prime}} V_{c^{\prime} f^{\prime}}^{*}}{\pi_{c^{\prime} f} V_{c^{\prime} f}^{*}}>\frac{\pi_{c f^{\prime}} V_{c f^{\prime}}^{*}+\pi_{c^{\prime} f^{\prime}} V_{c^{\prime} f^{\prime}}^{*}}{\pi_{c f} V_{c f}^{*}+\pi_{c^{\prime} f} V_{c^{\prime} f}^{*}}
\end{aligned}
$$

where $\pi_{c f}$ is the factor-productivity parameter for factor $f$ of country $c$. 


\section{CESifo Working Paper Series}

for full list see www.cesifo-group.org/wp

(address: Poschingerstr. 5, 81679 Munich, Germany, office@cesifo.de)

2188 Sándor Csengődi and Dieter M. Urban, Foreign Takeovers and Wage Dispersion in Hungary, January 2008

2189 Joerg Baten and Andreas Böhm, Trends of Children's Height and Parental Unemployment: A Large-Scale Anthropometric Study on Eastern Germany, 1994 2006, January 2008

2190 Chris van Klaveren, Bernard van Praag and Henriette Maassen van den Brink, A Public Good Version of the Collective Household Model: An Empirical Approach with an Application to British Household Data, January 2008

2191 Harry Garretsen and Jolanda Peeters, FDI and the Relevance of Spatial Linkages: Do third Country Effects Matter for Dutch FDI?, January 2008

2192 Jan Bouckaert, Hans Degryse and Theon van Dijk, Price Discrimination Bans on Dominant Firms, January 2008

2193 M. Hashem Pesaran, L. Vanessa Smith and Takashi Yamagata, Panel Unit Root Tests in the Presence of a Multifactor Error Structure, January 2008

2194 Tomer Blumkin, Bradley J. Ruffle and Yosef Ganun, Are Income and Consumption Taxes ever really Equivalent? Evidence from a Real-Effort Experiment with Real Goods, January 2008

2195 Mika Widgrén, The Impact of Council's Internal Decision-Making Rules on the Future EU, January 2008

2196 Antonis Adam, Margarita Katsimi and Thomas Moutos, Inequality and the Import Demand Function, January 2008

2197 Helmut Seitz, Democratic Participation and the Size of Regions: An Empirical Study Using Data on German Counties, January 2008

2198 Theresa Fahrenberger and Hans Gersbach, Minority Voting and Long-term Decisions, January 2008

2199 Chiara Dalle Nogare and Roberto Ricciuti, Term Limits: Do they really Affect Fiscal Policy Choices?, January 2008

2200 Andreas Bühn and Friedrich Schneider, MIMIC Models, Cointegration and Error Correction: An Application to the French Shadow Economy, January 2008

2201 Seppo Kari, Hanna Karikallio and Jukka Pirttilä, Anticipating Tax Change: Evidence from the Finnish Corporate Income Tax Reform of 2005, January 2008 
2202 Walter Krämer and André Güttler, On Comparing the Accuracy of Default Predictions in the Rating Industry, January 2008

2203 Syed M. Ahsan and Panagiotis Tsigaris, The Efficiency Loss of Capital Income Taxation under Imperfect Loss Offset Provisions, January 2008

2204 P. Mohnen, F. C. Palm, S. Schim van der Loeff and A. Tiwari, Financial Constraints and other Obstacles: Are they a Threat to Innovation Activity?, January 2008

2205 Sascha O. Becker and Mathias Hoffmann, Equity Fund Ownership and the CrossRegional Diversification of Household Risk, January 2008

2206 Pedro R. D. Bom and Jenny E. Ligthart, How Productive is Public Capital? A MetaAnalysis, January 2008

2207 Martin Werding, Ageing and Productivity Growth: Are there Macro-level Cohort Effects of Human Capital?, January 2008

2208 Frederick van der Ploeg and Steven Poelhekke, Globalization and the Rise of MegaCities in the Developing World, February 2008

2209 Sara Biancini, Regulating National Firms in a Common Market, February 2008

2210 Jin Cao and Gerhard Illing, Liquidity Shortages and Monetary Policy, February 2008

2211 Mathias Kifmann, The Design of Pension Pay Out Options when the Health Status during Retirement is Uncertain, February 2008

2212 Laszlo Goerke, Tax Overpayments, Tax Evasion, and Book-Tax Differences, February 2008

2213 Jun-ichi Itaya and Heinrich W. Ursprung, Price and Death, February 2008

2214 Valentina Bosetti, Carlo Carraro and Emanuele Massetti, Banking Permits: Economic Efficiency and Distributional Effects, February 2008

2215 Assar Lindbeck, Mårten Palme and Mats Persson, Social Interaction and Sickness Absence, February 2008

2216 Gary E. Bolton and Axel Ockenfels, The Limits of Trust in Economic Transactions Investigations of Perfect Reputation Systems, February 2008

2217 Hartmut Egger and Peter Egger, The Trade and Welfare Effects of Mergers in Space, February 2008

2218 Dorothee Crayen and Joerg Baten, Global Trends in Numeracy 1820-1949 and its Implications for Long-Run Growth, February 2008

2219 Stephane Dees, M. Hashem Pesaran, L. Vanessa Smith and Ron P. Smith, Identification of New Keynesian Phillips Curves from a Global Perspective, February 2008 
2220 Jerome L. Stein, A Tale of Two Debt Crises: A Stochastic Optimal Control Analysis, February 2008

2221 Michael Melvin, Lukas Menkhoff and Maik Schmeling, Automating Exchange Rate Target Zones: Intervention via an Electronic Limit Order Book, February 2008

2222 Raymond Riezman and Ping Wang, Preference Bias and Outsourcing to Market: A Steady-State Analysis, February 2008

2223 Lars-Erik Borge and Jørn Rattsø, Young and Old Competing for Public Welfare Services, February 2008

2224 Jose Apesteguia, Steffen Huck, Jörg Oechssler and Simon Weidenholzer, Imitation and the Evolution of Walrasian Behavior: Theoretically Fragile but Behaviorally Robust, February 2008

2225 Walter Krämer, Long Memory with Markov-Switching GARCH, February 2008

2226 António Afonso and Christophe Rault, What do we really Know about Fiscal Sustainability in the EU? A Panel Data Diagnostic, February 2008

2227 Sergey M. Kadochnikov and Igor M. Drapkin, Market Structure, Technological Gap and Vertical Linkage Effects from Foreign Direct Investment, February 2008

2228 Guglielmo Maria Caporale, Davide Ciferri and Alessandro Girardi, Fiscal Shocks and Real Exchange Rate Dynamics: Some Evidence for Latin America, February 2008

2229 Scott Alan Carson, Geography and Insolation in $19^{\text {th }}$ Century US African-American and White Statures, February 2008

2230 Wolfgang Buchholz and Jan Schumacher, Discounting and Welfare Analysis Over Time: Choosing the $\eta$, February 2008

2231 M. Hashem Pesaran, Christoph Schleicher and Paolo Zaffaroni, Model Averaging in Risk Management with an Application to Futures Markets, February 2008

2232 Wilhelm Kohler, Offshoring: Why Do Stories Differ?, February 2008

2233 Stefan Bach, Giacomo Corneo and Viktor Steiner, Effective Taxation of Top Incomes in Germany, 1992-2002, February 2008

2234 Robert S. Chirinko, $\sigma:$ The Long And Short Of It, February 2008

2235 Volker Grossmann and Holger Strulik, Should Continued Family Firms Face Lower Taxes than other Estates?, February 2008

2236 Guido Tabellini, The Scope of Cooperation: Values and Incentives, February 2008

2237 Heinrich W. Ursprung and Christian Wiermann, Reputation, Price, and Death: An Empirical Analysis of Art Price Formation, March 2008 
2238 Hans Fehr and Christian Habermann, Private Retirement Savings in Germany: The Structure of Tax Incentives and Annuitization, March 2008

2239 Joseph Francois and Ian Wooton, Market Structure and Market Access, March 2008

2240 Hiroyuki Kasahara and Beverly Lapham, Productivity and the Decision to Import and Export: Theory and Evidence, March 2008

2241 Gary E. Bolton and Axel Ockenfels, Does Laboratory Trading Mirror Behavior in Real World Markets? Fair Bargaining and Competitive Bidding on EBay, March 2008

2242 Atsushi Oshima, B. Ravikumar and Raymond Riezman, Entrepreneurship, Organization Capital and the Evolution of the Firm, March 2008

2243 Walter Krämer and Sebastian Schich, Large-Scale Disasters and the Insurance Industry, March 2008

2244 Leif Danziger, Adjustment Costs, Inventories and Output, March 2008

2245 Anne van Aaken, Lars P. Feld and Stefan Voigt, Power over Prosecutors Corrupts Politicians: Cross Country Evidence Using a New Indicator, March 2008

2246 Hans-Christian Heinemeyer, Max-Stephan Schulze and Nikolaus Wolf, Endogenous Borders? The Effects of New Borders on Trade in Central Europe 1885-1933, March 2008

2247 Johannes Becker and Clemens Fuest, Tax Competition - Greenfield Investment versus Mergers and Acquisitions, March 2008

2248 Giorgio Bellettini and Hubert Kempf, Why not in your Backyard? On the Location and Size of a Public Facility, March 2008

2249 Jose Luis Evia, Roberto Laserna and Stergios Skaperdas, Socio-Political Conflict and Economic Performance in Bolivia, March 2008

2250 Bas Jacobs and A. Lans Bovenberg, Optimal Taxation of Human Capital and the Earnings Function, March 2008

2251 Jan-Egbert Sturm and Timo Wollmershäuser, The Stress of Having a Single Monetary Policy in Europe, March 2008

2252 Guido Schwerdt, Labor Turnover before Plant Closure: 'Leaving the Sinking Ship' vs. 'Captain Throwing Ballast Overboard', March 2008

2253 Keith E. Maskus and Shuichiro Nishioka, Development-Related Biases in Factor Productivities and the HOV Model of Trade, March 2008 